\title{
Effects of protected area downsizing on habitat fragmentation in Yosemite National Park (USA), 1864 - 2014
}

\author{
Rachel E. Golden Kroner $^{1,2}, \underline{\text { Roopa Krithivasan }}^{3}$ and Michael B. Mascia $^{2}$
}

\begin{abstract}
Protected area downgrading, downsizing, and degazettement (PADDD) has been documented worldwide, but its impacts on biodiversity are poorly understood. To fill this knowledge gap, we reviewed historical documents to identify legal changes that altered the boundaries of Yosemite National Park. We identified two downsizes and five additions between 1905 and 1937 that reduced the size of Yosemite National Park by $30 \%$. To examine the effects of these downsizing events on habitat fragmentation by roads, we compared protected, never-protected, and downsized lands at three spatial scales using four habitat fragmentation metrics: road density, fragment (land surrounded by roads) area-to-perimeter ratio, fragment area, and fragment density. In general, lands that were removed from protection, e.g., downsized, were more highly fragmented than protected lands and indistinguishable from never-protected lands. Lands where downsizes were reversed were less fragmented than lands where downsizes were not reversed. These results suggest that protected area downsizing may exacerbate habitat fragmentation, a key contributor to biodiversity loss globally. Furthermore, the case study in Yosemite National Park demonstrates that iconic protected areas in developed countries are not immune to downsizing. These findings underscore the need to account for PADDD and governance histories in ecological research, monitoring, and evaluation. As we move toward more evidence-based conservation policy, a rigorous understanding of PADDD is essential to ensure that protected areas fulfill their promise as a strategy for conserving global biodiversity.
\end{abstract}

Key Words: downsizing; governance; habitat fragmentation; PADDD; protected areas; Yosemite National Park

\section{INTRODUCTION}

Habitat fragmentation is a well-documented threat to global biodiversity (Fischer and Lindenmayer 2007, Krauss et al. 2010, Haddad et al. 2015) driven by natural and anthropogenic factors. Anthropogenic habitat fragmentation affects biodiversity in myriad ways. Physical barriers that fragment landscapes often contribute to species loss and isolation (e.g., Gibson et al. 2013), reduced gene flow (e.g., Keller and Largiadèr 2003), changes in species composition (e.g., Laurance et al. 2006), and overall reduced biotic integrity (e.g., Trombulak and Frissell 2000). Habitat fragmentation may also compound the threat of climate change; for example, roads may prevent the migration of species attempting to adapt to a warming climate (Brodie et al. 2012).

Roads that fragment habitat have additional consequences for biodiversity. Documented effects of roads on wildlife include increased mortality from road construction and vehicle collisions, behavior modifications, alteration of the physical and chemical environments, and the spread of invasive species (Forman and Alexander 1998, Trombulak and Frissell 2000). Impacts of roads also occur during construction in the short or longer term (Spellerberg 1998). Roads can enable the development of extractive activities and contribute to additional infrastructure development near protected areas (PAs; Wade and Theobald 2010). Effects of roads on wildlife are largely negative, especially for amphibians and reptiles (Fahrig and Rytwinski 2009).

Terrestrial PAs are established to preserve large blocks of land, prevent habitat fragmentation, and conserve biodiversity (Margules and Pressey 2000, Hutton et al. 2005). PAs represent our primary global biodiversity conservation strategy; they help maintain ecosystem integrity or naturalness (Angermeier 2000, Ridder 2007) by setting restrictions on land-use, extraction, and other anthropogenic activities. In the United States, PAs are less fragmented than unprotected areas (Heilman et al. 2002). Though it is possible that less road construction occurs in PAs because they are disproportionately located in mountainous, remote locations (Joppa and Pfaff 2009), research controlling for these confounding variables suggests that PAs reduce habitat fragmentation (Sims 2014).

Legal changes that temper, shrink, or eliminate PAs may remove restrictions governing roads and thereby exacerbate habitat fragmentation. These legal changes, formally known as protected area downgrading, downsizing, and degazettement (PADDD), represent a widespread yet patchy global phenomenon driven by diverse causes (e.g., Mascia and Pailler 2011, Mascia et al. 2014). As defined by Mascia and Pailler (2011), downgrading is the legal allowance of additional anthropogenic activities in a PA, downsizing is the legal excision of a portion of a PA, and degazettement is the legal elimination of protection for an entire PA. Worldwide, at least 784 enacted PADDD events have occurred since 1900, affecting more than $664,000 \mathrm{~km}^{2}$ across 57 countries (Mascia et al. 2014, Forrest et al. 2015, Pack et al. 2016). Many PADDD events have occurred in the United States, which has experienced at least 240 enacted PADDD events since 1900 (R. E. Golden Kroner, R. Krithivasan, and M. B. Mascia, unpublished manuscript).

The impacts of PADDD are largely unknown; only two published studies have quantified these impacts (Forrest et al. 2015, Pack et al. 2016). Downsizing and degazettement have been linked to accelerated deforestation and increased carbon emissions in Peru and peninsular Malaysia (Forrest et al. 2015). PADDD has also been shown to have no significant impact on short-term deforestation rates in Brazil (Pack et al. 2016). However,

${ }^{1}$ Department of Environmental Science and Policy, George Mason University, ${ }^{2}$ Betty and Gordon Moore Center for Science, Conservation International, ${ }^{3}$ Department of Geography, Clark University 
relationships between PADDD and other ecological outcomes, including habitat fragmentation, have yet to be explored, especially in developed countries.

Given the global importance of PADDD and the dearth of empirical evidence about its impacts, we examine the ecological impacts of PADDD in Yosemite National Park, an iconic PA in the United States. We describe and map legal changes affecting Yosemite National Park since its gazettement, as well as document the proximate causes of these changes. We compare habitat fragmentation in previously protected lands, i.e., land excised from the Park, to fragmentation in corresponding still-protected and never-protected lands. Last, we explore the global implications of our findings for conservation science and policy.

\section{METHODS}

\section{Study site: Yosemite National Park and Sierra Nevada \\ Ecoregion, USA}

Yosemite National Park (hereafter, "the Park") is one of the oldest and most iconic national parks in the world. The Park is located in central California, USA, within the mountainous Sierra Nevada Ecoregion (hereafter, "the Ecoregion"). Ranging across California and Nevada, the Ecoregion's temperate conifer forests are characterized by high ecosystem and species diversity and endemism (Olson and Dinerstein 2002). Vegetation cover in the Ecoregion is dominated by cool temperate forest as well as polar and alpine cliff vegetation; a smaller proportion is covered with semidesert vegetation, shrub land, and grassland (USGS GAP 2011). The 38th Congress of the United States established the Yosemite Land Grant in 1864 (U.S. Congress 1864), the first significant national act to set aside land for preservation and public use. In 1890, Yosemite National Park was established (U. S. Congress 1890); in 1984, the Park was designated as a United Nations Educational, Scientific and Cultural Organization (UNESCO) World Heritage Site.

As of 2014, the Ecoregion area encompassed 151 PAs: 147 in California and 4 in Nevada (IUCN and UNEP-WCMC 2014). PAs in the Ecoregion fell into 28 designation categories, the most common of which were Wilderness Areas and Research Natural Areas. Most of the protected land, including Yosemite National Park, is included in a long corridor running north to south along the mountain range (Fig. 1).

\section{Data collection}

To examine the relationship between PADDD events and habitat fragmentation in Yosemite National Park, we used both historic and current literature and data. We reviewed historic documents and legal literature to document legal changes that affected Yosemite National Park, including enacted PADDD events, additions, and upgrades. We focused on the early history of the Park, from 1864 to 1937 , a time during which ongoing legal changes reshaped the Park's boundaries. We used an analytic narrative approach (Bates et al. 1998) to document the patterns, trends, proximate causes, and consequences of PADDD events in the Park. Through this approach, we systematically synthesized historical data on Yosemite's early history and used it to generate testable hypotheses about the impacts of boundary changes on landscape connectivity (Bates et al. 1998).
Fig. 1. Downsizes (enduring and reversed), protected areas, and never-protected areas in the Sierra Nevada Ecoregion and Yosemite National Park; roads shown only at the scale of Yosemite National Park

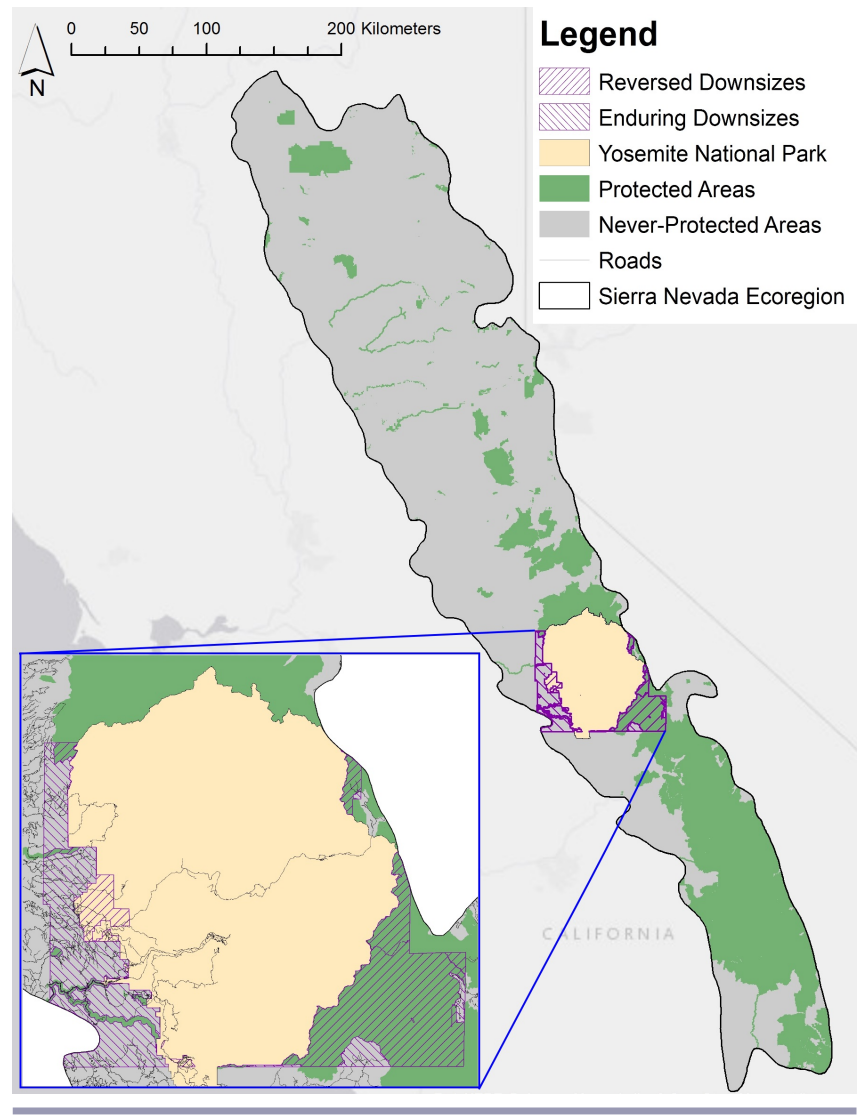

We examined legal and historic documents focused on Yosemite National Park. We obtained documents from the National Park Service History E-library website (NPS 2015a) and other web sources, which we searched using terms including: "Yosemite," "laws," "boundaries," "legal changes," and "Yosemite maps." The resulting documents included scholarly articles, books, and legal documents. We used established methods and decision trees to determine if a governance or boundary change constituted a PADDD event and characterized it either as a downgrade, downsize, or degazette (Mascia et al. 2012). For each PADDD event, we collected information for 22 different descriptive fields (detailed in the Appendix) following the technical guidance used for PADDDtracker.org (Mascia et al. 2012, WWF 2016). We also obtained historic paper maps of the Park using the U.S. Library of Congress archives. We digitized relevant and clear historical maps of the Park to document downsizes and additions to the park that changed the Park boundaries. To verify the accuracy of the map digitization, we referred to legislation describing the boundary changes (e.g., U.S. Congress 1905, U.S. Congress 1906) and other documents (Runte 1990).

To conduct the fragmentation analysis, we overlaid the Park boundaries with road data (U.S. Census Bureau 2014) for all roads 
located in the Sierra Nevada Ecoregion (Olson et al. 2001) in California and Nevada. We used only road spatial data to fragment habitat patches and calculate metrics indicating the degree of habitat fragmentation. Although this approach was limited because it did not include other infrastructure, e.g., railroads or pipelines, we focused on roads as a consistent, illustrative indicator. Roads may indicate the degree of a landscape's degradation and human access (Trombulak and Frissell 2000); road development may represent the "first cut" that leads to additional development (Laurance et al. 2014). For PA data, we utilized the World Database of Protected Areas (WDPA; IUCN and UNEP-WCMC 2014).

To focus on forest habitat, we conducted analyses for forested lands using the 2011 National Land Cover Dataset (Homer et al. 2015). We defined fragments (land parcels surrounded by roads on all sides) containing $>30 \%$ forest cover as forested using the conservative UNFCCC threshold definition (Sexton et al. 2015). As a robustness check, we also repeated the analyses for the entire ecoregion (Tables A1.8 - A1.16 detail results of robustness checks).

\section{Land governance type definitions}

We defined protected areas as those lands included in the 2014 version of the WDPA (IUCN and UNEP-WCMC 2014). For never-protected areas, we varied the size of the buffer (described below) and completed calculations for each, allowing us to test the sensitivity of our results. Under Tobler's law, we assumed that never-protected areas nearby the Park were biophysically similar to the Park (Tobler 1970). We used these 3 alternative buffers:

1. Lands within a $1 \mathrm{~km}$ buffer outside of the lands that are or once were protected as part of Yosemite National Park, including lands that are currently protected and lands that were downsized.

2. Lands within a $5 \mathrm{~km}$ buffer outside of the lands that are or once were protected as part of Yosemite National Park, including lands that are currently protected and lands that were downsized (Table A1.1, A1.2).

3. All unprotected lands within the Ecoregion except for the downsized lands near Yosemite National Park.

We included only downsize events (and not downgrades or degazettes) in the fragmentation analysis. To our knowledge, the only downsizes that have occurred in the Ecoregion were the two downsize events that changed the boundaries of the Park in 1905 and 1906. No known degazettes have occurred in the Ecoregion. Downgrade events have occurred in Yosemite National Park and other parks in the Ecoregion, but we did not consider them in our analysis of habitat fragmentation because of the uncertainty of their spatial locations.

We defined downsizes as portions of Yosemite National Park that were previously protected but excised from the Park because of enacted legal changes in 1905 and 1906. We defined reversed downsizes as lands that were previously removed from protection but are now currently within a PA (according to 2014 WDPA). We defined enduring downsizes as lands that were removed from protection and remain outside of the PA estate (according to the WDPA; IUCN and UNEP-WCMC 2014).

\section{Selection of habitat fragmentation indicators}

To quantify habitat fragmentation resulting from roads in Yosemite National Park and the Sierra Nevada Ecoregion, we used ArcGIS 10.1 to calculate three metrics for each land governance type: road density $\left(\mathrm{km}^{-1}\right)$; fragment (parcel of land surrounded by roads on all sides) area-to-perimeter ratio (area divided by perimeter squared, dimensionless; Bribiesca 1997); and fragment area $\left(\mathrm{km}^{2}\right)$. Statistical comparisons of these metricshigher road density, lower fragment area-to-perimeter ratio, and lower fragment area-indicated higher habitat fragmentation. These three metrics have been determined to have low collinearity with each other (low redundancy) and also have been used successfully to predict species richness (Lindenmayer et al. 2002). As a robustness check, we also calculated the fragment density $\left(\mathrm{km}^{-2}\right)$ by dividing the number of fragments in each parcel by the total area $\left(\mathrm{km}^{2}\right.$; Table A1.5; for a comprehensive investigation of habitat fragmentation metrics, see Schindler et al. 2015).

\section{Data analysis}

We statistically compared the values of three metrics (road density, fragment area, and fragment area-to-perimeter ratio) to characterize habitat fragmentation among different downsizing and protection categories at three spatial scales:

1. The downsize event: we compared lands that were downsized and later reincorporated into the PA estate (reversed downsizes) with lands that were downsized and remain unprotected (enduring downsizes).

2. The Park: we compared downsizes with lands inside the Park and never-protected lands $1 \mathrm{~km}$ from the Park. We compared lands with all three governance histories to each other and also compared each pair with post hoc tests. To verify the sensitivity of our results to the choice in buffer size, we also compared downsizes and protected lands with neverprotected lands $5 \mathrm{~km}$ from the Park.

3. The Ecoregion: we compared downsizes to all protected lands and all never-protected lands within the Ecoregion. We compared lands with all three governance histories to each other and also compared each pair.

As a robustness check, we also compared the values of fragment density among the downsizing and protection categories at the same spatial scales listed above.

We verified the distribution of the data for the three metrics (road density, fragment area-to-perimeter ratio, and fragment area) using the Shapiro Test and determined that none of these data were normally distributed; therefore we used nonparametric statistical tests. We ran Fligner-Killeen tests for homoscedasticity for each dataset (Table A1.3) to determine whether the data met the assumption of equal variance as required by Kruskal-Wallis and Mann-Whitney U tests. If the data were heteroscedastic, we then conducted either a Kruskal-Wallis or a Mann Whitney U test as appropriate. If the data were homoscedastic, we ran a Welch's Analysis of Variance (ANOVA) followed by post hoc Welch's t-tests. We performed all statistical tests using the $\mathrm{R}$ statistical package ( $\mathrm{R}$ Core Team 2014). We used an alpha value of 0.05 to indicate significance. 


\section{RESULTS}

Forest governance in Yosemite National Park, 1864-2014

Legal changes have shaped Yosemite National Park since its founding. After the establishment of the Yosemite Grant in 1864, advocates supported broad-scale preservation of the Yosemite region to end overgrazing and logging in the Park (Muir 1912). As a result of this advocacy, Yosemite National Park was signed into law on 1 October 1890 by President Harrison. Originally established under the jurisdiction of the state of California, the Park's enabling legislation prohibited human settlement, logging, mining, and hunting (U.S. Congress 1890), leading to the eviction of the Ahwahneechee people from the Yosemite Valley (Dowie 2009). Because the Park was so large, subsequent enforcement was present but not ubiquitous; boundaries were delineated on paper, but the Park was not fenced in nor fully patrolled. As a result, ranchers and hunters could illegally utilize Park resources on the fringes without being detected. In 1891, Park management was delegated to the U.S. Army, who monitored, patrolled, and enforced the new restrictions.

During the Park's early years, its popularity began to grow and shape the American experience. In 1864, the California State Supreme Court case Hutchings v. Low (Supreme Court of United States 1872) established that national parks were constitutional and also allowed licensed concessionaires to operate hotels, camps, toll roads, and transportation lines (Olmsted 1865). Paved roads and concessions were built in the early 1900s to enable tourist access and enhance visitor experiences (NPS 2015b). These roads immediately impacted Yosemite's native biota. As infrastructure was built, exotic vegetation (e.g., Kentucky blue grass [Poa pratensis] and timothy grass [Phleum pretense]) began to grow along roadsides (Gibbens and Heady 1964). Also, park managers suppressed fires in and around the Park, which allowed encroachment of fire-sensitive pines and cedars.

Early national parks in the United States typically set aside lands deemed useless, isolated, and devoid of economically valuable natural resources (Runte 1990). Soon after Yosemite was established, private interests began to advocate for legal changes that would excise natural resource-rich lands from the Park. The first acting superintendent of Yosemite, Captain Wood, wrote that the Park had been established "without having been previously introduced and considered in committee; hence no opportunity was given the people affected by it to be heard in any effort to modify its boundaries" (DOI 1891:xci). As a result, "about 65,000 acres of patented lands and also in the neighborhood of 300 mining claims" (DOI 1891:xci) were included in the park. Given the value of the timber, gold, and other minerals located within the Park, speculators and developers convinced Congress to remove some lands from protection (Jones 1965). In 1905, President Theodore Roosevelt signed legislation to remove 542 square miles $\left(1403.8 \mathrm{~km}^{2}\right)$ from the Park (U.S. Congress 1905). Excised Park lands were outside of core tourist areas to minimize visitor impacts; these downsizes were also located at lower elevations, making them more accessible for logging and mining.

As part of the 1905 legislation, 113 square miles $\left(292.67 \mathrm{~km}^{2}\right)$ were added to the Park. Hiram Chittenden, the Army Corps commissioner responsible for determining the boundary changes, justified the addition: "there are no patented or mineral lands in this tract" but instead, this added region possessed "features of great scenic beauty, notably the Hetch Hetchy Valley on the Tuolumne" (Chittenden 1895:4-5). An additional sixteen square miles $\left(41.44 \mathrm{~km}^{2}\right)$ was removed from the Park in 1906, primarily to enable logging (U.S. Congress 1906, Runte 1990) and, secondarily, to facilitate railroad access to the Park. The downsize events in 1905 and 1906 in Yosemite were both driven by industrial-scale forestry and mining interests (Runte 1990). These legal changes allowed for road construction and, thus, access to minerals and timber.

Road construction in the Park began early in its history, following legal changes to its status, i.e., downgrades. The first legal allowance of roads (specifically "free wagon roads or turnpikes") in Yosemite National Park was granted in 1892 (U.S. Congress 1892). An Act allowing additional "rights of way" including electrical lines, dams, and pipes through the Park was passed in 1901 (U.S. Congress 1901:790). In addition, the famous Hetch Hetchy dam was approved in 1913 after years of controversy (U. S. Congress 1913).

Changes to Yosemite's boundaries to allow timber and mineral extraction had immediate ecological consequences. As a result of boundary changes, some of the oldest trees nearby and expanses of wildlife habitat were lost or degraded (Runte 1990). In 1908, the acting superintendent wrote that "Game seems to be gradually on the decrease" as game had "grown fairly tame" and became an easy target for hunters (DOI 1906:653). In addition, certain lowlands and river valleys once suitable for winter refuge and breeding grounds for wildlife were no longer protected. These ecological changes were recorded during the same period that the downsizes of the Park occurred.

\section{Summary of quantitative changes to the boundaries of Yosemite} National Park

Following its establishment in 1890, the Park underwent a series of legal boundary changes from 1890 to 1937 (Fig. 2; Table A1.4). The boundary change of 1905 led to a $23.96 \%$ net reduction in Park lands: $1275.00 \mathrm{~km}^{2}$ were excised and $343.79 \mathrm{~km}^{2}$ were added to the Park. The boundary change of 1906 led to an additional loss of $34.30 \mathrm{~km}^{2}$. Four additions totaling $73.28 \mathrm{~km}^{2}$ were made to the Park in 1914, 1930, 1932, and 1937. The overall net change in the Park's area from 1890 to 1937 was $-29.80 \%$ (Table A1.4).

\section{Contemporary habitat fragmentation}

\section{The downsize event scale: enduring downsizes vs. reversed} downsizes

In 1964, 57\% of the land downsized from Yosemite was subsequently reprotected and reincorporated into the PA estate (reversed downsize), as part of the Ansel Adams and Hoover Wilderness Areas, while the remaining $43 \%$ of the downsized lands was not reincorporated (enduring downsize). Reversed downsizes had significantly lower road density than enduring downsizes and higher area-to-perimeter ratios, although the difference in area-to-perimeter ratios was not significant (Table 1). Reversed downsizes also had smaller fragment areas on average when compared to enduring downsizes, although the difference was not significant (Table 1). Furthermore, fragment density was higher in enduring downsizes when compared with reversed downsizes (Table A1.5). Taken together, these metrics indicate that habitat fragmentation was higher in enduring downsizes when compared to reversed downsizes. 
Fig. 2. Boundary changes of Yosemite National Park, 1890 - 1937

\section{Legend}

Lands Added to Yosemite National Park

Lands Previously Incorporated into Yosemite National Park

Lands Downsized from Yosemite National Park

1905: Downsize Event

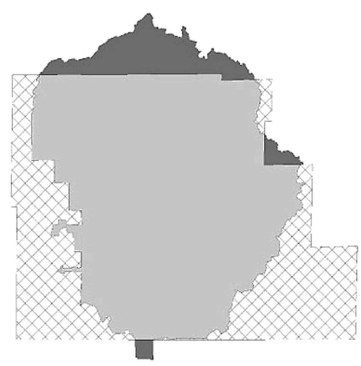

1930: Rockefeller Purchase

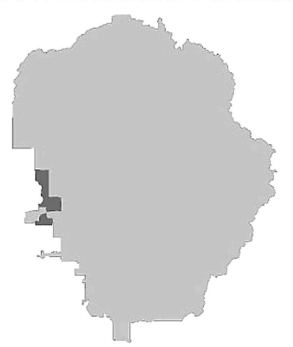

1864: Yosemite Grant

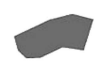

1906: Downsize Event

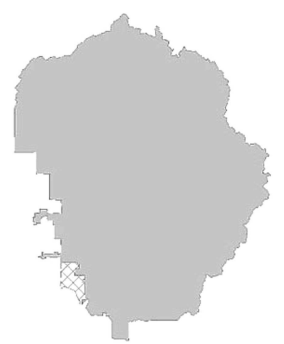

1932: Wawona Addition

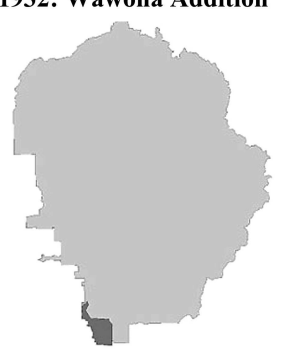

1890: Yosemite National Park Established

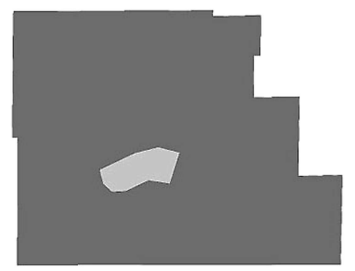

1914: Land and Timber Exchange

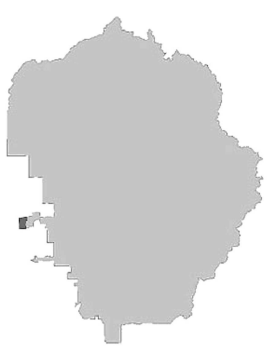

1937: Carl Inn Addition

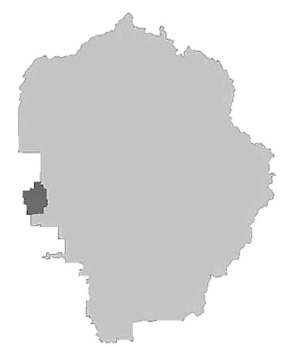

Table 1. Habitat fragmentation indicators in enduring and reversed downsizes for forested lands.

\begin{tabular}{lcccc}
\hline \hline Land governance types & Statistics & Road density $\left(\mathrm{km}^{-1}\right)$ & $\begin{array}{c}\text { Fragment }^{\dagger} \text { area-to-perimeter } \\
\text { ratio (dimensionless) }\end{array}$ & Fragment $^{\dagger}$ area $_{\left(\mathrm{km}^{2}\right)}$ \\
\hline Enduring downsizes & mean (SD) & $1.09(0.39)$ & $0.030(0.016)$ & $3.04(9.89)$ \\
& median (IQR) & $1.08(0.46)$ & $0.029(0.024)$ & $0.15(1.80)$ \\
& $n$ & $174^{\ddagger}$ & $160^{\S}$ & $160^{\S}$ \\
Reversed downsizes & mean (SD) & $0.59(0.51)$ & $0.032(0.017)$ & $8.84(62.91)$ \\
& median (IQR) & $0.36(0.92)$ & $0.032(0.028)$ & $0.05(0.66)$ \\
Results & $n$ & $151^{\ddagger}$ & $73^{\S}$ & $73^{\S}$ \\
& & $\mathrm{p}<0.001^{\mid}$ & $\mathrm{p}=0.28^{\mathrm{Il}}$ & $\mathrm{p}=0.44^{\mid}$ \\
& $\mathrm{df}=279.41$ & $\mathrm{~W}=5319$ & $\mathrm{df}=73.63$ \\
\end{tabular}

$\dagger$ Fragment: parcel of land surrounded by roads on all sides, $\quad{ }^{\ddagger}$ Number of points sampled, ${ }^{\S}$ Number of fragments

'Welch's t-test result; choice of test based on Fligner-Killeen test for homoscedasticity (see Table A1.3)

${ }^{\mathbb{I}}$ Mann-Whitney U test result; choice of test based on Fligner-Killeen test for homoscedasticity (see Table A1.3) 
The Park scale

Comparisons of metrics among the Park, never-protected lands around the Park, and downsized (both enduring and reversed) lands were generally consistent with results at the downsize event scale. A comparison of road density among the three land tenure classes demonstrated that all pair-wise differences between land tenure classes in terms of road density were significant (Table A1.6). Downsizes had intermediate road density; never-protected areas had the highest road density while the Park had the lowest (Table 2).

Fragment area-to-perimeter ratios were significantly higher inside the Park when compared with both downsized and neverprotected lands (Table 2; Table A1.6). Never-protected and downsized lands were not significantly different from each other in terms of fragment area-to-perimeter ratios, indicating a degree of similarity between the two land governance types (Table A1.6).

There were no significant differences in fragment area among the Park, downsized, and never-protected lands. However, on average, fragment areas inside the Park were larger than downsized fragments or never-protected fragments (Table 2). This suggests that there are more large roadless lands inside the Park than immediately outside. In addition, measurements of fragment density showed that never-protected lands were highest, followed by downsizes, and then the Park lands (Table A1.5). For all metrics, the use of different buffer sizes for never-protected areas did not affect the results (Table A1.1, A1.2). Overall, these metrics provide strong evidence that fragmentation was higher in downsizes when compared with the Park and preliminary evidence that fragmentation was higher in downsizes when compared to never-protected lands.

\section{The Ecoregion scale}

At the ecoregion scale, all pair-wise differences in road density among the three land tenure types were statistically significant (Table 3, Table A1.7). Similar to results at the Park scale, downsizes had intermediate road density between never-protected and protected lands in the Ecoregion. In addition, all pairwise differences in area-to-perimeter ratio between land governance types were statistically significant (Table A1.7). Area-toperimeter ratio results at the Ecoregional scale were unexpected; protected lands had the lowest area-to-perimeter ratios on average, followed by downsizes and never-protected lands (Table 3). Fragment area measurements revealed that downsizes were not significantly different when compared to protected and neverprotected lands in the Ecoregion. In addition, fragment density measures for never-protected lands were the highest, followed by protected and then downsized lands (Table A1.5). Overall, three out of four of these metrics show that fragmentation was higher in never-protected lands when compared to downsized and protected lands.

\section{DISCUSSION}

\section{Implications for conservation science}

The history of Yosemite National Park highlights the dynamic nature of PA governance. Though researchers have previously described PA governance dynamics (Adams 2004, Agrawal 2005, Naughton-Treves et al. 2006), many studies assume that PAs and other conservation interventions will endure in perpetuity.
Emerging evidence demonstrates that PADDD is widespread in both developing (Mascia and Pailler 2011, Mascia et al. 2014, Bernard et al. 2014) and developed nations, including Australia (Watson et al. 2014), and the United States (Mascia and Pailler 2011; R. E. Golden Kroner, R. Krithivasan, and M. B. Mascia, unpublished manuscript) though the rates of PADDD on national scales remain unclear. In the case of Yosemite, the emergence and evolution of the Park over 150 years illustrates the complexity and diversity of PA governance. The Park experienced additions and upgrades as well as downgrades and downsizes, some of which endured and some of which were reversed, even decades later. These legal changes were largely driven by pressures to reshape Park governance to enable natural resource extraction. Our findings underscore the need to account for PADDD and governance histories more generally in ecological research and conservation studies around the world.

In Yosemite National Park, environmental governance has shaped the landscape. PA downsizing led to higher habitat fragmentation at multiple spatial scales. The one exception was the surprising result that at the Ecoregional scale, protected areas had lower area-to-perimeter ratios, i.e., were more highly fragmented, than either downsized or never-protected lands. These results may suggest that PAs in the Ecoregion do not provide large areas of core habitat. The most common type of PAs in the Ecoregion are IUCN category V (Protected Landscapes and Seascapes; $45 \%$ of PAs), which are subject to multiple use management. More research is needed to confirm the hypothesis that the dominance of less strictly protected areas in the Ecoregion explains the surprising result of higher fragmentation in protected areas. Despite this exception, findings for all other metrics demonstrate the negative impact of PADDD on habitat integrity. These findings are consistent with previous observations by Forrest et al. (2015) that PADDD increases rates of tropical deforestation and carbon emissions in developing countries. Cases similar to that of Yosemite involving road construction in and around protected areas are found around the world. For instance, the development of a proposed road in Tanzania's Serengeti National Park is expected to affect wildebeest migration, increase public access, and accelerate poaching (Gadd 2015:455) but remains contentious because of its perceived socioeconomic benefits (Fyumagwa et al. 2013).

Our study of Yosemite has demonstrated the negative ecological effects of PADDD, supporting the findings of previous studies that have quantified the benefits of PAs. Establishment of PAs can foster ecological integrity by reducing rates of deforestation and habitat fragmentation (Andam et al. 2008, Nolte et al. 2013, Sims 2014). However, even large protected areas like Yosemite are not sufficient to preserve viable populations of carnivores (Newmark 1985), the conservation of which may be further compromised by PADDD. Only two studies to date (Forrest et al. 2015, Pack et al. 2016) have examined the impacts of PADDD, demonstrating the need for further research. For instance, longterm studies are needed to understand the relationships between PADDD, habitat loss and fragmentation, and long-term impacts on species; extinctions can occur decades after a habitat is degraded (Brooks et al. 1999). In addition, future research could examine the impacts of PADDD on ecosystems beyond forests, ecosystem services, and human well-being. 
Table 2. Habitat fragmentation indicators at the Park scale for forested lands; results of Welch's ANOVA tests. See Table A1.6 for results of post-hoc tests.

\begin{tabular}{|c|c|c|c|c|}
\hline Land governance type & Statistics & Road density $\left(\mathrm{km}^{-1}\right)$ & $\begin{array}{l}\text { Fragment }^{\dagger} \text { area-to-perimeter } \\
\text { ratio (dimensionless) }\end{array}$ & Fragment ${ }^{\dagger}$ area $\left(\mathrm{km}^{2}\right)$ \\
\hline \multirow[t]{3}{*}{ Downsizes } & mean (SD) & $0.86(0.51)$ & $0.035(0.015)$ & $6.96(46.70)$ \\
\hline & median (IQR) & $0.95(0.94)$ & $0.034(0.023)$ & $0.14(1.33)$ \\
\hline & $n$ & $331^{\ddagger}$ & $167^{\S}$ & $167^{\S}$ \\
\hline \multirow[t]{3}{*}{ Yosemite National Park } & mean (SD) & $0.38(0.235)$ & $0.042(0.015)$ & 21.37 (168.87) \\
\hline & median (IQR) & $0.25(0.46)$ & $0.042(0.020)$ & $0.020(0.17)$ \\
\hline & $n$ & $762^{\ddagger}$ & $141^{\S}$ & $141^{\S}$ \\
\hline \multirow[t]{3}{*}{$\begin{array}{l}\text { Never-protected lands } \\
\text { (1-km buffer) }\end{array}$} & mean (SD) & $1.27(0.44)$ & $0.032(0.012)$ & $0.99(1.94)$ \\
\hline & median (IQR) & $1.29(0.59)$ & $0.031(0.015)$ & $0.42(1.11)$ \\
\hline & $n$ & $27^{\ddagger}$ & $80^{\S}$ & $80^{\S}$ \\
\hline \multirow[t]{4}{*}{ Results } & & $\mathrm{p}<0.001$ & $\mathrm{p}<0.001$ & $\mathrm{p}=0.10$ \\
\hline & & $F=163.98$ & $\mathrm{~F}=14.48$ & $\mathrm{~F}=2.38$ \\
\hline & & num $\mathrm{df}=2$ & num $\mathrm{df}=2$ & num $\mathrm{df}=2$ \\
\hline & & denom $\mathrm{df}=68.04$ & denom $\mathrm{df}=223.60$ & denom df $=203.24$ \\
\hline
\end{tabular}

Table 3. Habitat fragmentation indicators at the Ecoregional scale for forested lands; results of Welch's ANOVA tests. See Table A1.7 for results of post hoc tests.

\begin{tabular}{|c|c|c|c|c|}
\hline Area Name & Statistics & Road density $\left(\mathrm{km}^{-1}\right)$ & $\begin{array}{l}\text { Fragment }^{\dagger} \text { area-to-perimeter } \\
\text { ratio (dimensionless) }\end{array}$ & Fragment $^{\dagger}$ area $\left(\mathrm{km}^{2}\right)$ \\
\hline \multirow[t]{3}{*}{ Downsizes } & mean (SD) & $0.86(0.51)$ & $0.035(0.015)$ & $6.96(46.70)$ \\
\hline & median (IQR) & $0.95(0.94)$ & $0.034(0.023)$ & $0.14(1.33)$ \\
\hline & $n$ & $331^{\ddagger}$ & $167^{\S}$ & $167^{\S}$ \\
\hline \multirow[t]{3}{*}{$\begin{array}{l}\text { All protected lands in Sierra } \\
\text { Nevada Ecoregion }\end{array}$} & mean (SD) & $0.39(0.50)$ & $0.029(0.020)$ & $6.39(79.98)$ \\
\hline & median (IQR) & $0.19(0.52)$ & $0.028(0.033)$ & $0.025(0.25)$ \\
\hline & $n$ & $3468^{\ddagger}$ & $1750^{\S}$ & $1750^{\S}$ \\
\hline \multirow[t]{7}{*}{$\begin{array}{l}\text { All never-protected lands in } \\
\text { Sierra Nevada Ecoregion }\end{array}$} & mean $(\mathrm{SD})$ & $1.48(0.68)$ & $0.036(0.015)$ & $2.92(17.70)$ \\
\hline & median (IQR) & $1.43(0.82)$ & $0.035(0.023)$ & $0.17(1.02)$ \\
\hline & $n$ & $12991^{\ddagger}$ & $11774^{\S}$ & $11774^{\S}$ \\
\hline & $\mathrm{p}$ & $\mathrm{p}<0.001$ & $\mathrm{p}<0.001$ & $\mathrm{p}=0.11$ \\
\hline & $\mathrm{F}$ & $F=5561.79$ & $F=99.77$ & $F=2.25$ \\
\hline & num df & num $\mathrm{df}=2$ & num $\mathrm{df}=2$ & num $\mathrm{df}=2$ \\
\hline & denom df & denom df $=889.11$ & denom df $=419.34$ & denom df $=406.30$ \\
\hline
\end{tabular}

\footnotetext{
${ }^{\dagger}$ Fragment: parcel of land surrounded by roads on all sides, $\quad{ }^{\ddagger}$ Number of points sampled, ${ }^{\S}$ Number of fragments
} 
The ecological consequences of PADDD reveal the importance of incorporating governance histories into analyses of conservation impacts. As calls for evidence-based conservation grow (Sutherland et al. 2004, DANIDA 2006, Ferraro and Pattanayak 2006, USAID 2011), researchers are increasingly examining the impacts of protected areas and other conservation interventions through methods designed to ensure causal inference (Andam et al. 2008, Robalino and Pfaff 2013). Impacts of conservation interventions are often estimated by examining them as static entities. To provide accurate estimates of impact, however, our findings highlight the need for such studies to recognize and incorporate the history of boundary changes and governance shifts, e.g., PADDD, that may no longer appear in official ledgers, e.g., PA databases. Without incorporating discontinued or abandoned interventions and other confounding factors, studies may generate biased estimates of impact through biases in sampling of treatment and/or control sites.

\section{Implications for conservation policy}

Governance in Yosemite National Park evolved over decades, but was particularly dynamic in the earliest years as rules changed and boundaries shifted dramatically. These initial large shifts in governance, followed by more recent periods of relative stability, suggest that PA establishment may be followed by a protracted period of adjustment and refinement. Accordingly, rather than consider PA establishment as the end of a policy-making process, initial legal designation may represent a milestone in a much longer (potentially decades-long) process of institutionalizing borders and rules governing land use. Community-based natural resource management, payments for ecosystem services, ecocertification schemes, and other conservation interventions may experience similar dynamics, continuing to evolve (sometimes rapidly) in the years and even decades after establishment. Dynamic governance of conservation interventions and their continued evolution postestablishment suggests the need for a broad shift in mindset among conservation scholars, practitioners, and donors.

With the advantage of a 150-year time period, our study also highlights the significant impacts of re-establishing protection years after PADDD. Redesignating protections over previously downsized forests, even decades after the fact, resulted in reduced habitat fragmentation within these reprotected lands. As Forrest et al. (2015) note, though PADDDed lands may represent areas of unstable governance, they also may retain the ecological and social values that led to the intervention in the first place. Alongside exploration of wholly new sites for conservation, reprotection of lands and waters, e.g., PADDD reversals, associated with protected areas and other discontinued conservation interventions merits serious consideration as a conservation strategy.

\section{CONCLUSION}

As the National Park Service, the first protected area system in the world, celebrates its 100th anniversary in 2016, an historical perspective of the dynamic governance of Yosemite National Park provides globally relevant insights. An understanding of early governance of national parks provides context and enriches our understanding of conservation interventions both in the United States and around the world. By looking back, we can move forward with a more informed understanding of these interventions. Accounting for PADDD from the beginning of a nation's protected area estate to understand its temporal evolution and impacts informs progress toward national and international conservation goals (Mascia et al. 2014). Failure to monitor PADDD could bias conservation planning and policies, resulting in inefficient or suboptimal outcomes. Integrating information about PADDD and its reversals into tracking conservation progress, such as the Convention on Biological Diversity Aichi target 11 (CBD 2010), would provide more nuanced and comprehensive understanding of conservation progress and potential backsliding (Watson et al. 2014). As we move to more evidence-based conservation policy, a rigorous understanding of PADDD is essential to ensure that PAs fulfill their promise as a strategy for conserving biodiversity in the United States and worldwide.

Responses to this article can be read online at: http://www.ecologyandsociety.org/issues/responses. $\mathrm{php} / 8679$

\begin{abstract}
Acknowledgments:
Thank you to the World Wildlife Fund Conservation Science Program and the University of Maryland College Park Sustainable Development and Conservation Biology Program for institutional support during the early phase of this project. Thank you also to $K$. Haisfield for assisting with map digitization, B. Fagan for reviewing an early draft of the manuscript, and two anonymous reviewers for providing valuable comments. Publication of this article was funded in part by the George Mason University Libraries Open Access Publishing Fund. This work was also supported in part by generous gifts to Conservation International from Gordon and Betty Moore and the Gordon and Betty Moore Foundation.
\end{abstract}

\section{LITERATURE CITED}

Adams, W. M. 2004. Against extinction: the story of conservation. Earthscan, London, UK.

Agrawal, A. 2005. Environmentality: technologies of government and the making of subjects. Duke University Press, Durham, North Carolina, USA. http://dx.doi.org/10.1215/9780822386421

Andam, K. S., P. J. Ferraro, A. Pfaff, G. A. Sanchez-Azofeifa, and J. A. Robalino. 2008. Measuring the effectiveness of protected area networks in reducing deforestation. Proceedings of the National Academy of Sciences 105:16089-16094. http://dx.doi. org/10.1073/pnas.0800437105

Angermeier, P. L. 2000. The natural imperative for biological conservation. Conservation Biology 14:373-381. http://dx.doi. org/10.1046/j.1523-1739.2000.98362.X

Bates, R. H., A. Greif, M. Levi, and J. Rosenthal. 1998. Analytic narratives. Princeton University Press, Princeton, New Jersey, USA.

Bernard, E., L. A. O. Penna, and E. Araújo. 2014. Downgrading, downsizing, degazettement, and reclassification of protected areas in Brazil. Conservation Biology 28:939-950. http://dx.doi. org/10.1111/cobi.12298 
Bribiesca, E. 1997. Measuring 2-D shape compactness using the contact perimeter. Computers and Mathematics with Applications 33:1-9. http://dx.doi.org/10.1016/S0898-1221(97)00082-5

Brodie, J., E. Post, and W. F. Laurance. 2012. Climate change and tropical biodiversity: a new focus. Trends in Ecology \& Evolution 27:145-150. http://dx.doi.org/10.1016/j.tree.2011.09.008

Brooks, T. M., S. L. Pimm, and J. O. Oyugi. 1999. Time lag between deforestation and bird extinction in tropical forest fragments. Conservation Biology 5:1140-1150. http://dx.doi.org/10.1046/ j.1523-1739.1999.98341.x

Chittenden. H. M. 1895. The Yellowstone National Park: report of the Yosemite Park Commission. Robert Clarke Company, Cincinnati, Ohio, USA.

Convention on Biological Diversity (CBD). 2010. Decision adopted by the Conference of the Parties to the Convention on Biological Diversity at Its Tenth Meeting. Nagoya, Aichi Prefecture, Japan, 18-29 October 2010. Secretariat to the Convention on Biological Diversity, Montréal, Québec, Canada.

Danish International Development Agency (DANIDA). 2006. Evaluation guidelines. Ministry of Foreign Affairs, Copenhagen, Denmark.

Department of the Interior (DOI). 1891. Report of the Acting Superintendent of the Yosemite National Park. Government Printing Office, Washington, D.C., USA.

Department of the Interior (DOI). 1906. Annual Report of the Department of the Interior. Government Printing Office, Washington, D.C., USA.

Dowie, M. 2009. Conservation refugees: the hundred-year conflict between global conservation and native peoples. MIT Press, Cambridge, UK.

Fahrig, L., and T. Rytwinski. 2009. Effects of roads on animal abundance: an empirical review and synthesis. Ecology and Society 14(1):21. [online] URL: http://www.ecologyandsociety. org/vol14/iss1/art21/

Ferraro, P. J., and S. K. Pattanayak. 2006. Money for nothing? A call for empirical evaluation of biodiversity conservation investments. PLoS Biology 4(4):e105. http://dx.doi.org/10.1371/ journal.pbio.0040105

Fischer, J., and D. B. Lindenmayer. 2007. Landscape modification and habitat fragmentation: a synthesis. Global Ecology and Biogeography 16:265-280. http://dx.doi.org/10.1111/ j.1466-8238.2007.00287.x

Forman, R. T. T., and L. E. Alexander. 1998. Roads and their major ecological effects. Annual Review of Ecology and Systematics 29:207-231. http://dx.doi.org/10.1146/annurev. ecolsys.29.1.207

Forrest, J. L., M. B. Mascia, S. Pailler, S. Z. Abidin, M. D. Araujo, R. Krithivasan, and J. C. Riveros. 2015. Tropical deforestation and carbon emissions from protected area downgrading, downsizing, and degazettement (PADDD). Conservation Letters 8:153-161. http://dx.doi.org/10.1111/conl.12144

Fyumagwa, R., E. Gereta, S. Hassan, S., J. R. Kideghesho, E. M. Kohi, J. Keyyu, F. Magige, I. M. Mfunda, A. Mwakatobe, J.
Ntalwila, J. W. Nyahongo, V. Runyoro, and E. Røskaft. 2013. Roads as a threat to the Serengeti ecosystem. Conservation Biology 27:1122-1125. http://dx.doi.org/10.1111/cobi.12116

Gadd, M. E. 2015. Expected effects of a road across the Serengeti. Pages 455-464 in R. van der Ree, D. J. Smith, and C. Grilo, editors. Handbook of road ecology. First Edition. Wiley and Sons, Hoboken, New Jersey, USA. http://dx.doi.org/10.1002/9781118568170. $\underline{\mathrm{ch} 56}$

Gibbens, R. P., and H. F. Heady. 1964. The influence of modern man on the vegetation of Yosemite Valley. University of California Berkley, Division of Agricultural Sciences, Berkley, California, USA. http://dx.doi.org/10.5962/bhl.title.61201

Gibson, L., A. J. Lynam, C. J. A. Bradshaw, F. He, D. P. Bickford, D. S. Woodruff, S. Bumrungsri, and W. F. Laurance. 2013. Nearcomplete extinction of native small mammal fauna 25 years after forest fragmentation. Science 341:1508-1510. http://dx.doi. org/10.1126/science.1240495

Haddad, N. M., L. A. Brudvig, J. Clobert, K. F. Davies, A. Gonzalez, R. D. Holt, T. E. Lovejoy, J. O. Sexton, M. P. Austin, C. D. Collins, W. M. Cook, E. I. Damschen, R. M. Ewers, B. L. Foster, C. N. Jenkins, A. J. King, W. F. Laurance, D. J. Levey, C. R. Margules, B. A. Melbourne, A. O. Nicholls, J. L. Orrock, D.X. Song, and J. R. Townshend. 2015. Habitat fragmentation and its lasting impact on Earth's ecosystems. Science Advances 1: e1500052. http://dx.doi.org/10.1126/sciadv.1500052

Heilman, G. E., Jr, J. R. Strittholt, N. C. Slosser, and D. A. Dellasala. 2002. Forest fragmentation of the conterminous United States: assessing forest intactness through road density and spatial characteristics: forest fragmentation can be measured and monitored in a powerful new way by combining remote sensing, geographic information systems, and analytical software. BioScience 52:411-422. http://dx.doi.org/10.1641/0006-3568 (2002)052[0411:FFOTCU]2.0.CO;2

Homer, C.G., J. A. Dewitz, L. Yang, S. Jin, P. Danielson, G. Xian, G., J. Coulston, N. D. Herold, J. D. Wickham, K. and Megown. 2015. Completion of the 2011 National Land Cover Database for the conterminous United States-Representing a decade of land cover change information. Photogrammetric Engineering and Remote Sensing 81(5):345-354.

Hutton, J., W. M. Adams, and J. C. Murombedzi. 2005. Back to the barriers? Changing narratives in biodiversity conservation. Forum for Development Studies 32:341-370. http://dx.doi. org/10.1080/08039410.2005.9666319

International Union for the Conservation of Nature (IUCN) and United Nations Environment Program's World Conservation Monitoring Center (UNEP-WCMC). 2014. The world database on protected areas (WDPA). January 2015 Release. UNEPWCMC, Cambridge, UK. [online] URL: http://www. protectedplanet.net

Jones, H. R. 1965. John Muir and the Sierra Club: the battle for Yosemite. Sierra Club, San Francisco, California, USA. [online] URL: http://vault.sierraclub.org/john muir exhibit/ bibliographic_resources/book_jackets/jm_and_sc_jones_jacket.aspx

Joppa, L. N., and A. Pfaff. 2009. High and far: biases in the location of protected areas. PLOS ONE 4:e8273. http://dx.doi. org/10.1371/journal.pone.0008273 
Keller, I., and C. R. Largiadèr. 2003. Recent habitat fragmentation caused by major roads leads to reduction of gene flow and loss of genetic variability in ground beetles. Proceedings of the Royal Society of London B: Biological Sciences 270:417-423. http://dx. doi.org/10.1098/rspb.2002.2247

Krauss, J., R. Bommarco, M. Guardiola, R. K. Heikkinen, A. Helm, M. Kuussaari, R. Lindborg, E. Öckinger, M. Pärtel, J. Pino, J. Pöyry, K. M. Raatikainen, A. Sang, C. Stefanescu, T. Teder, M. Zobel, and I. Steffan-Dewenter. 2010. Habitat fragmentation causes immediate and time-delayed biodiversity loss at different trophic levels. Ecology Letters 13:597-605. http://dx.doi. org/10.1111/j.1461-0248.2010.01457.x

Laurance, W. F., G. R. Clements, S. Sloan, C. S. O'Connell, N. D. Mueller, M. Goosem, O. Venter, D. P. Edwards, B. Phalan, A. Balmford, R. Van Der Ree, and I. B. Arrea. 2014. A global strategy for road building. Nature 513:229-232. http://dx.doi.org/10.1038/ nature 13717

Laurance, W. F., H. E. M. Nascimento, S. G. Laurance, A. Andrade, J. E. L. S. Ribeiro, J. P. Giraldo, T. E. Lovejoy, R. Condit, J. Chave, K. E. Harms, and S. D'Angelo. 2006. Rapid decay of tree-community composition in Amazonian forest fragments. Proceedings of the National Academy of Sciences 103:19010-19014. http://dx.doi.org/10.1073/pnas.0609048103

Lindenmayer, D. B., R. B. Cunningham, C. F. Donnelly, and R. Lesslie. 2002. On the use of landscape surrogates as ecological indicators in fragmented forests. Forest Ecology and Management 159:203-216. http://dx.doi.org/10.1016/S0378-1127(01)00433-9

Margules, C. R., and R. L. Pressey. 2000. Systematic conservation planning. Nature 405:243-253. http://dx.doi.org/10.1038/35012251

Mascia, M. B., and S. Pailler. 2011. Protected area downgrading, downsizing, and degazettement (PADDD) and its conservation implications. Conservation Letters 4:9-20. http://dx.doi. org/10.1111/j.1755-263X.2010.00147.X

Mascia, M. B., S. Pailler, and R. Krithivasan. 2012. PADDDtracker.org technical guide (Version 1). World Wildlife Fund. Washington, D.C., USA.

Mascia, M. B., S. Pailler, R. Krithivasan, V. Roshchanka, D. Burns, M. J. Mlotha, D. R. Murray, and N. Peng. 2014. Protected area downgrading, downsizing, and degazettement (PADDD) in Africa, Asia, and Latin America and the Caribbean, 1900-2010. Biological Conservation 169:355-361. http://dx.doi.org/10.1016/j. biocon.2013.11.021

Muir, J. 1912. The Yosemite, 1838-1914. Century Company, New York, New York, USA. [online] URL: http://vault.sierraclub.org/ john muir exhibit/writings/the yosemite/

National Park Service (NPS). 2015a. National Park Service history e-library. NPS, Washington, D.C., USA. [online] URL: http:// www.nps.gov/parkhistory/hisnps/NPSarchives.htm

National Park Service (NPS). 2015b. Yosemite Valley loop road project. NPS, Washington, D.C., USA. http://www.nps.gov/yose/ learn/management/valleyloop.htm

Naughton-Treves L., N. Alvarez-Berr, K. Brandon, A. Bruner, M. Holland, C. Ponce, M. Saenz, L. Suarez, and A. Treves. 2006. Expanding protected areas and incorporating human resource use: a study of 15 forest parks in Ecuador and Peru. Sustainability. Science, Practice, and Policy 2:32-44.

Newmark, W. D. 1985. Legal and biotic boundaries of western North American national parks: a problem of congruence. Biological Conservation 33:197:208. http://dx.doi.org/10.1016/0006-3207 (85)90013-8

Nolte, C., A. Agrawal, K. M. Silvius, and B. S. Soares-Filho. 2013. Governance regime and location influence avoided deforestation success of protected areas in the Brazilian Amazon. Proceedings of the National Academy of Sciences 110:4956-4961. http://dx.doi. org/10.1073/pnas. 1214786110

Olmsted, F. L. 1865. The Yosemite Valley and the Mariposa Big Tree Grove: a preliminary report. America's National Park System: the critical documents. NPS, Washington, D.C., USA. [online] URL: http://www.nps.gov/parkhistory/online books/anps/anps $1 \mathrm{~b}$. $\underline{\text { htm }}$

Olson, D. M., and E. Dinerstein. 2002. The global 200: priority ecoregions for global conservation. Annals of the Missouri Botanical Garden 89(2):199-224. http://dx.doi.org/10.2307/3298564

Olson, D. M., E. Dinerstein, E. D. Wikramanayake, N. D. Burgess, G. V. N. Powell, E. C. Underwood, J. A. D'amico, I. Itoua, H. E. Strand, J. C. Morrison, C. J. Loucks, T. F. Allnutt, T. H. Ricketts, Y. Kura, J. F. Lamoreux, W. W. Wettengel, P. Hedao, and K. R. Kassem. 2001. Terrestrial ecoregions of the world: a new map of life on Earth. A new global map of terrestrial ecoregions provides an innovative tool for conserving biodiversity. BioScience 51:933-938. http://dx.doi.org/10.1641/0006-3568(2001)051[0933: TEOTWA]2.0.CO;2

Pack, S. M., M. N. Ferreira, R. Krithivasan, J. Murrow, E. Bernard, and M. B. Mascia. 2016. Protected area downgrading, downsizing, and degazettement (PADDD) in the Amazon. Biological Conservation 197:32-39. http://dx.doi.org/10.1016/j. biocon.2016.02.004

R Core Team. 2014. R: A language and environment for statistical computing. R Foundation for Statistical Computing, Vienna, Austria. [online] URL: http://www.r-project.org/

Ridder, B. 2007. An exploration of the value of naturalness and wild nature. Journal of Agricultural and Environmental Ethics 20:195-213. http://dx.doi.org/10.1007/s10806-006-9025-6

Robalino, J., and A. Pfaff. 2013. Ecopayments and deforestation in Costa Rica: a nationwide analysis of PSA's initial years. Land Economics 89:432-448. http://dx.doi.org/10.3368/le.89.3.432

Runte, A. 1990. Yosemite: the embattled wilderness. University of Nebraska Press, Lincoln, Nebraska, USA.

Schindler, S., H. von Wehrden, K. Poirazidis, W. M. Hochachka, T. Wrbka, and V. Kati. 2015. Performance of methods to select landscape metrics for modelling species richness. Ecological Modelling 295:107-112. http://dx.doi.org/10.1016/j.ecolmodel.2014.05.012

Sexton, J. O., P. Noojipady, X. P. Song, M. Feng, D. X. Song, D. H. Kim, A. Anand, C. Huang, S. Channan, S. L. Pimm, and J. R. Townshend. 2016. Conservation policy and the measurement of forests. Nature Climate Change 6:192-196. 
Sims, K. R. E. 2014. Do protected areas reduce forest fragmentation? A microlandscapes approach. Environmental and Resource Economics 58:303-333. http://dx.doi.org/10.1007/ s10640-013-9707-2

Spellerberg, I. 1998. Ecological effects of roads and traffic: a literature review. Global Ecology and Biogeography 7:317-333. http://dx.doi.org/10.1046/j.1466-822x.1998.00308.x

Supreme Court of United States. 1872. The Yosemite Valley Case. Hutchings v. Low. 82 U.S. 77. 15 Wall. 77, 21 L. Ed. 82. Supreme Court of United States, Washington, D.C., USA. [online] URL: https://www.law.cornell.edu/supremecourt/text/82/77

Sutherland, W. J., A. S. Pullin, P. M. Dolman, and T. M. Knight. 2004. The need for evidence-based conservation. Trends in Ecology \& Evolution 19:305-308. http://dx.doi.org/10.1016/j. $\underline{\text { tree.2004.03.018 }}$

Tobler, W. R. 1970. A computer movie simulating urban growth in the Detroit region. Economic Geography 46:234-240. http://dx. doi.org/10.2307/143141

Trombulak, S. C., and C. A. Frissell. 2000. Review of ecological effects of roads on terrestrial and aquatic communities. Conservation Biology 14:18-30. http://dx.doi.org/10.1046/ j.1523-1739.2000.99084.X

U.S. Agency for International Development (USAID). 2011. USAID evaluation policy. U.S. Agency for International Development, Washington, D.C., USA.

U.S. Census Bureau. 2014. 2014 TIGER/Line Shapefiles. [Machine-readable data files]. U.S. Census Bureau, Washington, D.C., USA. [online] URL: https://www.census.gov/geo/mapsdata/data/tiger-line.html

U.S. Congress. 1864. S. 203; Public Act 159. An Act Authorizing a Grant to the State of California of the Yosemite Valley and of the Land embracing the Mariposa Big Tree Grove. U.S. Statutes at Large 13(184):325.

U.S. Congress. 1890. H.R. 12187. An Act to set apart certain tracts of land in the State of California as forest reservations. U.S. Statutes at Large 26(1263):650-652.

U.S. Congress. 1892. An act granting to the County of Mariposa, in the State of California, the right of way for a free wagon road or turnpike across the Yosemite National Park, in the said state. U.S. Statutes at Large 27(205):235-36.

U.S. Congress. 1901. H.R. 11973. An Act Relating to rights of way through certain parks, reservations, and other public lands. U.S. Statutes at Large 31(372):790-791.

U.S. Congress. 1905. H.R. 17345; Public Act 49. An Act to exclude from the Yosemite National Park, California, certain lands therein described, and to attach and include the said lands in the Sierra Forest Reserve. U.S. Statutes at Large 33(547):702-703.

U.S. Congress. 1906. H.J.R. 118; Public Resolution 27. Joint resolution Accepting the recession by the State of California of the Yosemite Valley Grant and the Mariposa Big Tree Grove, and including the same, together with fractional sections five and six, township five south, range twenty-two east, Mount Diablo meridian, California, within the metes and bounds of the
Yosemite National park, and changing the boundaries thereof. U.S. Statutes at Large 34(27):831-832.

U.S. Congress. 1913. H.R. 7207, Public Act 41. An Act Granting to the city and county of San Francisco certain rights of way in, over, and through certain public lands, the Yosemite National Park, and Stanislaus National Forest, and certain lands in the Yosemite National Park, the Stanislaus National Forest, and the public lands in the State of California, and for other purposes. $U$. S. Statutes at Large 38(4):242-251.

U.S. Geological Survey Gap Analysis Program (USGS GAP). 2011. National land cover, Version 2. USGS, Reston, Virginia, USA. [online] URL: http://gapanalysis.usgs.gov/gaplandcover/ viewer/

Wade, A. A., and D. M. Theobald. 2010. Residential development encroachment on U.S. protected areas. Conservation Biology 24:151-161. http://dx.doi.org/10.1111/j.1523-1739.2009.01296.x

Watson, J. E. M., N. Dudley, D. B. Segan, and M. Hockings. 2014. The performance and potential of protected areas. Nature 515:67-73. http://dx.doi.org/10.1038/nature13947

World Wildlife Fund (WWF). 2016. PADDDtracker: Tracking protected area downgrading, downsizing, and degazettement [Beta version]. WWF, Washington, D.C., USA. [online] URL: http:// www.PADDDtracker.org 
Golden Kroner, R. E., R. Krithivasan, and M. B. Mascia. 2016. Effects of protected area downsizing on habitat fragmentation in Yosemite National Park (USA), 1864 - 2014. Ecology and Society 21(3).

Appendix 1: Supplemental Methods, Supplemental Tables A1.1 to A1.16, and Supplemental Literature Cited

\section{SUPPLEMENTAL METHODS}

Study site

All IUCN categories are represented in the Ecoregion except National Monuments (IUCN III) and National Wildlife Refuges (VI). Protected Landscapes (IUCN V) are the most common (45\% of protected areas in the Ecoregion), followed by Wilderness Areas, IUCN Ib (26\%) and Strict Wilderness Areas, IUCN Ia (14\%), Habitat and Species Management Areas IV (11\%), and National Parks (2\%).

\section{Data collection and formatting}

For each PADDD event, we collected information for 22 different descriptive fields: Continent, Country, ISO Country Code, WDPA ID, WDPA Name, Primary Name, All Names, Event Type (downgrade, downsize, or degazette), Enacted or Proposed, Year PA Gazetted, Year of PADDD event, Proximate Cause, Area Affected, Size of PA before PADDD $\left(\mathrm{km}^{2}\right)$, Size of PA after PADDD $\left(\mathrm{km}^{2}\right)$, IUCN category before PADDD, IUCN category after PADDD, Reversal (yes/no), Offset (yes/no), Systemic Change (yes/no), Sources, and Supporting Information. These fields correspond with the existing data structure used in PADDDtracker.org (WWF 2016) and the technical guidance upon which these data are based (Mascia et al. 2012).

For all spatial data, we conducted calculations at the appropriate projection for central California. We used the NAD 1983 State Plane California III FIPS coordinate system within the GCS North American 1983 Geographic Coordinate System and North American 1983 datum. We digitized maps in ArcGIS 10.1 by scanning each paper map (Greene 1987; Huber 1987), rendering it in GIS, aligning it with landscape features including state and other protected area boundaries, topography, and rivers, and tracing the map by hand using the georeferencing tool bar. The maps that we used for analyses were derived from Greene (1987); the source map included a scale bar in graphic scale format. To assess accuracy, we manually measured the scale bar and converted it to ratio scale using the formula (SFEI 2016):

Ratio scale $=1: \mathrm{X} \mathrm{km}$ (represented by scale bar) $* 100,000 \mathrm{~cm} / \mathrm{km} \div \mathrm{X} \mathrm{cm}$ (measured on map)

We determined that the scale of the original map was 1:392,439. Given best-practice guidelines for reporting uncertainty (Wieczorek 2001), the value can be estimated as $1 \mathrm{~mm}$ in relation to the scale. Hence, the uncertainty of the measurement was $392.439 \mathrm{~km}$. 
In addition, we reviewed the language of supporting documents to verify the analyses to the extent possible. For instance, we validated the digitized polygons by comparing the calculated areas of the downsizings with text from Runte (1990), which stated that one third of 
the Park area was removed from protection in 1905. Calculations of area based on digitization show that $32.81 \%$ of the Park area was removed; in this case, the calculation underestimates the area of the downsize by less than $1 \%$.

To create the protected area layer, we clipped the WDPA 2014 polygon layer using the Sierra Nevada Ecoregion from the Terrestrial Ecoregions of the World dataset (Olson et al. 2001). In the WDPA, Yosemite is included on two rows: as a National Park and a wilderness area. We merged these together to create the Yosemite layer. We included all roads (US Census Bureau 2014) located in each of the 21 counties in California and each of the three counties in Nevada that overlap with the Sierra Nevada region. We merged the 24 road shapefiles together and clipped them using the Sierra Nevada Ecoregion to create the road layer. The US Census Bureau data includes information for different types of roads, including primary, secondary, and tertiary paved roads, as well as unpaved roads, bike paths, and trails. The majority of the roads located in the Ecoregion are paved "local neighborhood roads, rural roads, or city streets" $(89.9 \%)$, followed by "private roads for service vehicles (logging, oil fields, ranches, etc.)" (6.4\%), and "vehicular trails" - unpaved roads which require a four-wheel-drive $(2.0 \%)$. The remaining road categories each comprise less than $1 \%$ of the total road network. Roads which are paved and wide enough to allow for vehicle traffic comprise $>99 \%$ of the road network in the Ecoregion. We determined that eliminating roads which are unpaved and are too narrow to allow vehicle traffic (bike paths, hiking trails) was not likely to affect the results. We treated all roads equally in the analysis as it was outside the scope of this study to weight the road classes based on ecological significance or contribution to habitat fragmentation.

We created the fragments by clipping the protected, never-protected, and downsizes polygons into smaller pieces (fragments) using the roads layer. The 1905 downsizes area extended outside of the Sierra Nevada Ecoregion on the western edge, so we clipped it to fit within the Ecoregion. This clipped an area of $<1 \%$ of the downsize extent and did not affect the results. We created the downsize lands polygons by digitizing paper maps (Greene 1987; Huber 1987) in ArcGIS. We then clipped these layers to the extent of the Sierra Nevada Ecoregion layer and merged them together. This shapefile included two downsizes: one that occurred in 1905 and one that occurred in 1906. We completed calculations for both downsize events together as well as for reversed and enduring downsizes.

To prepare the never-protected areas, we first created a layer for all lands that are currently and were previously protected within the Park. To do this, we combined the current protected area extent of the Park with areas that had been downsized. We then used the lands that are protected now or were protected previously as a reference when creating the never-protected lands. We used three different options for never-protected lands:

1. Never-protected lands option 1: We created a $1 \mathrm{~km}$ buffer in ArcGIS around the areas that are currently or were previously protected as part of the Park.

2. Never-protected lands option 2: We created a $5 \mathrm{~km}$ buffer in ArcGIS around the areas that are currently or were previously protected as part of the Park.

3. Never-protected lands option 3: We created a never-protected lands layer covering the entire Sierra Nevada region by erasing all protected areas, including the lands previously 
and currently protected in Yosemite National Park, from the Sierra Nevada Ecoregion polygon layer.

For all fragment layers, we removed fragments that were smaller than $0.001 \mathrm{~km}^{2}$ in area to eliminate map drawing errors. We also manually checked each fragment for map errors in GIS. We identified and deleted three additional data points that were an artifact of map drawing errors. This process affected the calculations for fragment area and area-to-perimeter ratio as these calculations are dependent on each other, but did not affect calculations for road density which were calculated independently of fragment layers.

\section{Road metrics calculations details}

We created fragments by first converting the polygons for each land governance type to polylines. We then merged these polylines with the road layer clipped to the extent of each land governance type. We then converted the merged shapefile (roads and boundaries together) into polygons to form the fragments layer. The resultant attribute tables for the fragment layers served as the basis for calculations for fragment area-to-perimeter ratio and fragment area.

We calculated road metrics for total area, fragment area, and fragment area-to-perimeter ratio in ArcGIS using the geometry calculator in each attribute table. We also used attribute tables to count the number of fragments. We calculated road density using the Line Density tool in ArcGIS for all roads using an output cell size of 1408.02, a search radius of 11733.50 (default values for the whole Sierra Nevada Ecoregion, the largest extent in the study). We converted the resultant raster to points and then clipped this to the extent of each land governance type. We report means and standard deviations, as well as medians and IQR values, for line density values.

To analyze the data for forested lands only, we used the National Land Cover Database (NLCD; Homer et al. 2015) clipped to the extent of the Sierra Nevada Ecoregion in the same projection as used previously. When re-projecting the raster, we used the nearest neighbor resampling approach with an output cell size of 30 . For the analysis, we extracted and included only land cover types that are categorized as forest (e.g. deciduous, evergreen, and mixed) and excluded all other land cover types. Forest land cover types comprise $60.08 \%$ of the Ecoregion, which is dominated by evergreen forest (58.56\% of the Ecoregion). The next most common land cover type is shrub land (26.88\%) followed by barren land $(6.04 \%)$, grassland $(3.20 \%)$, and open water $(2.09 \%)$. The remaining land cover types each comprise less than $1 \%$ of the extent of the Ecoregion. To calculate the fragment area and area-to-perimeter ratio values, we used only fragments that contained greater than $30 \%$ forested area; this is the conservative threshold to define a forest used by the United Nations Framework for the Convention on Climate Change (Sexton et al. 2016). Although there is a range of thresholds that can be applied to define a forest ranging from $10 \%$ to $60 \%$ (as noted in Sexton et al. 2016), we chose a value within the middle of the acceptable range which is utilized by an authoritative source. To calculate road density for forested areas, we clipped the road density points to the extent of the forest polygon that was derived from the NLCD. We ran the same statistical tests, including the Fligner-Killeen test for 
homoscedasticity, the appropriate test based on the Fligner-Kileen result (e.g. either Welch's ttest or Mann Whitney U), and the appropriate post-hoc tests as necessary. Results are consistent with the results calculated across the entire Ecoregion. The values of the metrics are slightly different when using forested lands only, but the significances of all statistical results are identical with two exceptions. The Fligner-Killeen test at the downsize scale is not significant when using all lands (leading us to use the Mann-Whitney $U$ test) and is significant for forest lands (leading us to use the Welch's t-test).In addition, the Fligner-Killeen test at the Park scale using $1 \mathrm{~km}$ buffers is not significant when using all lands (leading us to use the KruskallWallis/Mann-Whitney U test) and is significant for forested lands (leading us to use the Welch's ANOVA and t-test.

Although we used several different sized buffers of never-protected areas to which to compare protected and downsized lands, we recognize that lands nearby the park are not necessarily biophysically similar to lands within the Park. For instance, it is possible that the Park boundaries may have been drawn initially to exclude certain lands which are more suitable for development, timber harvesting, or agriculture. Future research is required to determine whether this selection bias affects the results found here. We attempted to minimize errors in these calculations by using consistent projections and calculation methods. Numbers presented here are intended to be an estimate, rather than definitive values, of the parameters in question and serve as points of comparison between each land governance type that we examined. 


\section{SUPPLEMENTAL TABLES}

Table A1.1: Habitat fragmentation indicators at the Park scale for forested lands - sensitivity test using a $5 \mathrm{~km}$ never-protected lands buffer demonstrate the same results as with a $1 \mathrm{~km}$ buffer.

See Table A1.2 for results of post-hoc tests.

\begin{tabular}{|c|c|c|c|c|}
\hline $\begin{array}{l}\text { Land governance } \\
\text { type }\end{array}$ & Statistics & Road density $\left(\mathrm{km}^{-1}\right)$ & $\begin{array}{l}\text { Fragment }^{\dagger} \text { area- } \\
\text { to-perimeter ratio } \\
\text { (dimensionless) }\end{array}$ & $\begin{array}{c}\text { Fragment }{ }^{\dagger} \text { area } \\
\qquad\left(\mathrm{km}^{2}\right)\end{array}$ \\
\hline \multirow[t]{3}{*}{ Downsizes } & mean $(\mathrm{SD})$ & $0.86(0.51)$ & $0.035(0.015)$ & $6.96(46.70)$ \\
\hline & $\begin{array}{l}\text { median } \\
(\mathrm{IQR})\end{array}$ & $0.95(0.94)$ & $0.034(0.023)$ & $0.14(1.33)$ \\
\hline & $n$ & $331^{\ddagger}$ & $167^{\S}$ & $167^{\S}$ \\
\hline \multirow{3}{*}{$\begin{array}{l}\text { Yosemite } \\
\text { National Park }\end{array}$} & mean (SD) & $0.38(0.235)$ & $0.042(0.015)$ & $21.37(168.87)$ \\
\hline & $\begin{array}{c}\text { median } \\
(\mathrm{IQR})\end{array}$ & $0.25(0.46)$ & $0.042(0.020)$ & $0.020(0.17)$ \\
\hline & $n$ & $762^{+}$ & $141^{\S}$ & $141^{\S}$ \\
\hline \multirow[t]{3}{*}{$\begin{array}{l}\text { Never-protected } \\
(5 \mathrm{~km} \text { buffer })\end{array}$} & mean (SD) & $1.23(0.45)$ & $0.032(0.014)$ & $2.50(6.97)$ \\
\hline & $\begin{array}{l}\text { median } \\
\text { (IQR) }\end{array}$ & $1.32(0.63)$ & $0.031(0.018)$ & $0.37(2.23)$ \\
\hline & $n$ & $177^{\star}$ & $183^{\S}$ & $183^{\S}$ \\
\hline \multirow[t]{3}{*}{ Results } & & $\mathrm{p}<0.001^{l}$ & $\mathrm{p}<0.001^{\#}$ & $\mathrm{p}=0.20^{l}$ \\
\hline & & $\mathrm{F}=349.13$ & $\chi^{2}=32.80$ & $\begin{array}{c}F=1.61 \\
\end{array}$ \\
\hline & & $\begin{array}{c}\text { num df }=2 \\
\text { denom df }=391.70\end{array}$ & df $=2$ & $\begin{array}{c}\text { num di }=2 \\
\text { denom df }= \\
206.50\end{array}$ \\
\hline
\end{tabular}

${ }^{\dagger}$ Fragment: parcel of land surrounded by roads on all sides

$\$$ Number of points sampled

$\S$ Number of fragments

'Welch's ANOVA test result. Choice of test based on Fligner-Killeen test for homoscedasticity (see Table A1.3)

\# Kruskal-Wallis test result. Choice of test based on Fligner-Killeen test for homoscedasticity (see Table A1.3) 
Table A1.2: Post-hoc results from Table A1.1. Habitat fragmentation at the Park scale for forested lands using $5 \mathrm{~km}$ buffers for never-protected lands. Results are consistent with comparisons using a $1 \mathrm{~km}$ buffer.

\begin{tabular}{lccc}
\hline \hline & $\begin{array}{c}\text { Fragment } \\
\text { to-perimeter } \\
\text { ratio }\end{array}$ & $\begin{array}{c}\text { Fragment } \\
\text { Comparison }\end{array}$ & $\begin{array}{c}\left.\mathrm{km}^{2}\right) \\
(\text { dimensionless })\end{array}$ \\
\hline Downsized vs. the Park & $\begin{array}{c}\mathrm{p}<0.001^{\ddagger} \\
\mathrm{t}=15.58\end{array}$ & $\mathrm{p}<0.001^{\S}$ & $\mathrm{p}=0.33^{\ddagger}$ \\
& $\mathrm{df}=472.52$ & $\mathrm{t}=0.98$ \\
Downsized vs. Never & $\mathrm{p}<0.001^{\ddagger}$ & $\mathrm{p}=0.19^{\S}$ & $\mathrm{df}=158.11$ \\
Protected (5 km buffer) & $\mathrm{t}=-8.38$ & $\mathrm{~W}=14050$ & $\mathrm{p}=0.22^{\ddagger}$ \\
& $\mathrm{df}=399.08$ & $\mathrm{t}=-1.22$ \\
The Park vs. Never- & $\mathrm{p}<0.001^{\ddagger}$ & $\mathrm{p}<0.001^{\S}$ & $\mathrm{df}=172.76$ \\
Protected (5 km buffer) & $\mathrm{t}=29.45$ & $\mathrm{~W}=17639$ & $\mathrm{p}=0.19$ \\
& $\mathrm{df}=761.00$ & $\mathrm{t}=1.33$ \\
\hline
\end{tabular}

$\dagger$ Fragment: parcel of land surrounded by roads on all sides

$\$$ Welch's t-test result. Choice of test based on Fligner-Killeen test for homoscedasticity (see Table A1.3)

$\S$ Mann-Whitney U test result. Choice of test based on Fligner-Killeen test for homoscedasticity (see Table A1.3) 
Table A1.3: Results of Fligner-Killeen tests for homoscedasticity for forested lands indicating which statistical test(s) to perform next at all three spatial scales.

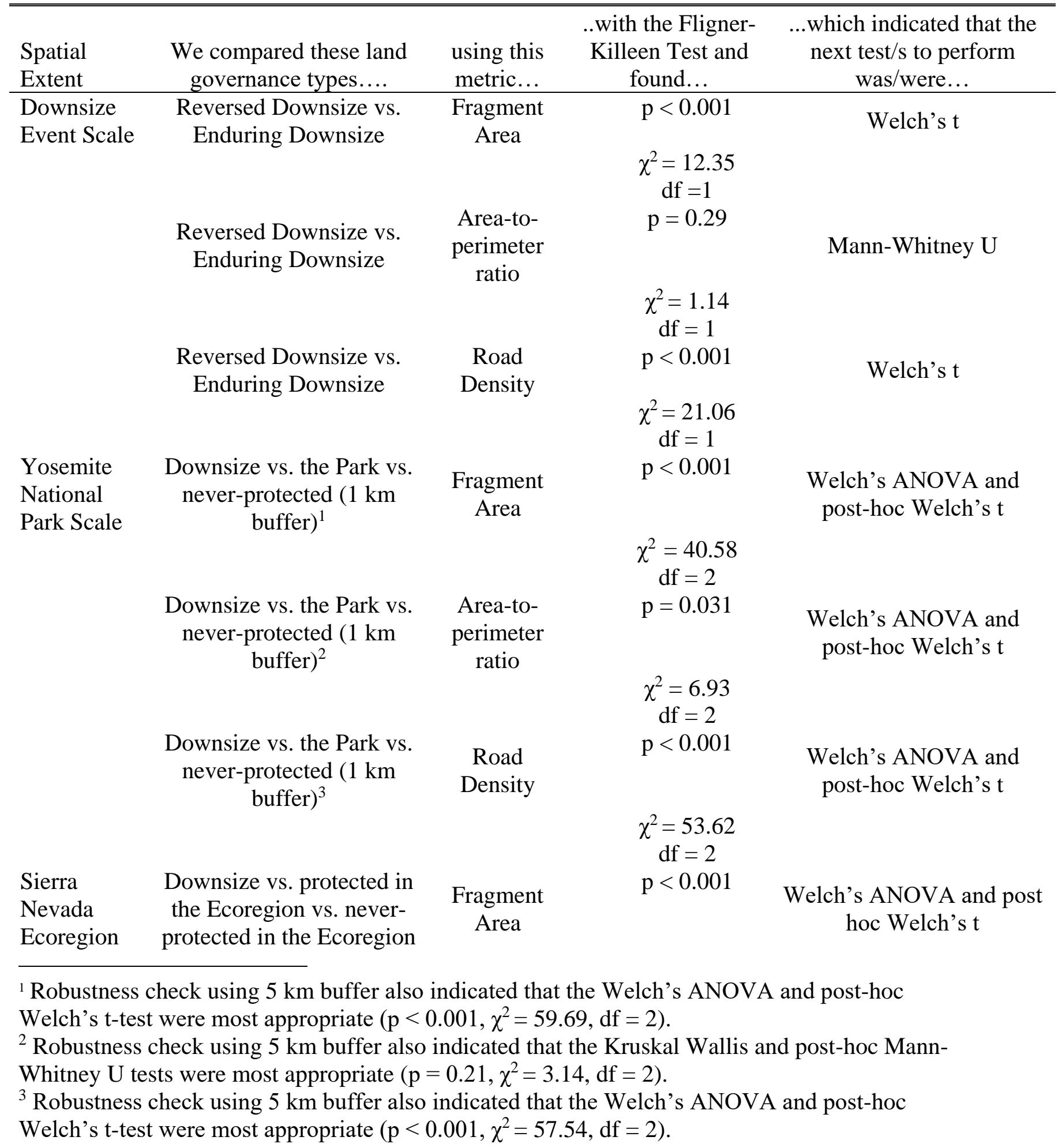


Scale

Downsize vs. protected in the Ecoregion vs. neverprotected in the Ecoregion

Downsize vs. protected in the Ecoregion vs. neverprotected in the Ecoregion

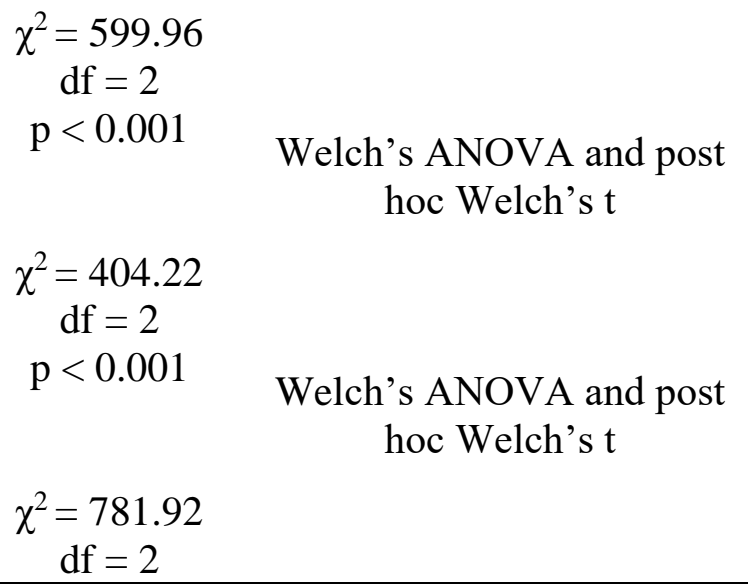


Table A1.4: Timeline of Yosemite Boundary Adjustments in Yosemite National Park. Area values calculated in ArcGIS 10.1.

\begin{tabular}{|c|c|c|c|c|c|}
\hline Year & Event Name & $\begin{array}{l}\text { Net Area } \\
\text { Affected } \\
\left(\mathrm{km}^{2}\right)\end{array}$ & $\begin{array}{l}\text { Area of the } \\
\text { Park After } \\
\text { Event }\left(\mathrm{km}^{2}\right)\end{array}$ & $\begin{array}{l}\text { Percent change } \\
\text { of Park Area } \\
\text { after event }(\%)\end{array}$ & Source \\
\hline 1864 & $\begin{array}{l}\text { Yosemite Grant } \\
\text { Established }\end{array}$ & 125.23 & 125.23 & $\mathrm{n} / \mathrm{a}$ & $\begin{array}{c}\text { H.R. } 12187 \\
1964\end{array}$ \\
\hline 1890 & $\begin{array}{l}\text { Yosemite National } \\
\text { Park Established }\end{array}$ & 3886.10 & 3886.10 & $\mathrm{n} / \mathrm{a}$ & Runte 1990 \\
\hline 1905 & $\begin{array}{l}\text { Land Exclusion } \\
\text { (downsize) }\end{array}$ & -1275.00 & 2611.10 & -32.81 & $\begin{array}{c}\text { Runte 1990; } \\
\text { H.R. } 17345 \\
1905\end{array}$ \\
\hline 1905 & $\begin{array}{l}\text { Land Offset } \\
\text { (addition) }\end{array}$ & 343.79 & 2954.89 & 13.17 & Runte 1990 \\
\hline 1906 & $\begin{array}{l}\text { Land Exclusion } \\
\text { (downsize) }\end{array}$ & -34.30 & 2920.59 & -1.16 & $\begin{array}{c}\text { Runte 1990; } \\
\text { H.J.R. } 118 \\
1906\end{array}$ \\
\hline 1914 & $\begin{array}{c}\text { Land and Timber } \\
\text { Exchange (addition) }\end{array}$ & 4.52 & 2925.11 & 0.15 & 16 USC $\$ 51$ \\
\hline 1930 & $\begin{array}{c}\text { Rockefeller } \\
\text { Purchase (addition) }\end{array}$ & 34.34 & 2959.45 & 1.17 & Lloyd 1930 \\
\hline 1932 & $\begin{array}{l}\text { Wawona Addition } \\
\text { (addition) }\end{array}$ & 34.42 & 2993.87 & 1.16 & Runte 1990 \\
\hline 1937 & $\begin{array}{l}\text { Carl Inn Addition } \\
\text { (addition) }\end{array}$ & unknown & unknown & unknown & $\mathrm{n} / \mathrm{a}$ \\
\hline
\end{tabular}


Table A1.5: Fragment density calculations at three spatial scales for forested lands

\begin{tabular}{lccc}
\hline \hline Land governance type & Total Area $\left(\mathrm{km}^{2}\right)$ & $\begin{array}{c}\text { Number of } \\
\text { fragments }\end{array}$ & $\begin{array}{c}\text { Fragment }^{\dagger} \\
\text { density }\left(\mathrm{km}^{-2}\right)\end{array}$ \\
\hline Enduring Downsize & 486.6 & 160 & 0.33 \\
Reversed Downsize & 645.25 & 73 & 0.11 \\
All Downsized lands & 1162.65 & 167 & 0.14 \\
Yosemite National Park & 3013.02 & 141 & 0.047 \\
Never-protected lands - 1 km buffer & 79.24 & 80 & 1.01 \\
Never-protected lands- 5 km buffer & 457.44 & 183 & 0.40 \\
All protected lands in the Ecoregion & 11184.07 & 1750 & 0.16 \\
All never-protected lands in the & 34411.17 & 11774 & 0.34 \\
Ecoregion & & & \\
\hline
\end{tabular}

${ }^{\dagger}$ Fragment: parcel of land surrounded by roads on all sides 
Table A1.6: Habitat fragmentation at the Park scale for forested lands - post-hoc Welch's t-tests results from Table 2 .

\begin{tabular}{|c|c|c|c|}
\hline Comparison & $\begin{array}{l}\text { Road density } \\
\qquad\left(\mathrm{km}^{-1}\right)\end{array}$ & $\begin{array}{c}\text { Fragment }^{\dagger} \text { area- } \\
\text { to-perimeter } \\
\text { ratio } \\
\text { (dimensionless) }\end{array}$ & $\begin{array}{l}\text { Fragment }{ }^{\dagger} \text { area } \\
\qquad\left(\mathrm{km}^{2}\right)\end{array}$ \\
\hline Downsized vs. the Park & $\begin{aligned} \mathrm{p} & <0.001 \\
\mathrm{t} & =15.58 \\
\mathrm{df} & =472.52\end{aligned}$ & $\begin{aligned} \mathrm{p} & <0.001 \\
\mathrm{t} & =-4.17 \\
\mathrm{df} & =299.26\end{aligned}$ & $\begin{array}{c}\mathrm{p}=0.33 \\
\mathrm{t}=-0.98 \\
\mathrm{df}=158.11\end{array}$ \\
\hline Downsized vs. Never-Protected & $\begin{array}{c}\mathrm{p}<0.001 \\
\mathrm{t}=-4.55 \\
\mathrm{df}=31.97\end{array}$ & $\begin{array}{c}\mathrm{p}=0.24 \\
\mathrm{t}=1.18 \\
\mathrm{df}=191.59\end{array}$ & $\begin{array}{c}\mathrm{p}=0.10 \\
\mathrm{t}=1.65 \\
\mathrm{df}=167.19\end{array}$ \\
\hline The Park vs. Never-Protected & $\begin{array}{l}\mathrm{p}<0.001 \\
\mathrm{t}=-10.34 \\
\mathrm{df}=27.20\end{array}$ & $\begin{array}{c}\mathrm{p}<0.001 \\
\mathrm{t}=5.03 \\
\mathrm{df}=192.92\end{array}$ & $\begin{array}{c}\mathrm{p}=0.15 \\
\mathrm{t}=1.43 \\
\mathrm{df}=140.07\end{array}$ \\
\hline
\end{tabular}

$\dagger$ Fragment: parcel of land surrounded by roads on all sides 
Table A1.7: Habitat fragmentation at the Ecoregional scale for forested lands - post-hoc tests results of Welch's t-tests from Table 3.

\begin{tabular}{|c|c|c|c|c|}
\hline Comparison & Statistics & $\begin{array}{l}\text { Road density } \\
\left(\mathrm{km}^{-1}\right)\end{array}$ & $\begin{array}{c}\text { Fragment }^{\dagger} \text { area- } \\
\text { to-perimeter } \\
\text { ratio } \\
\text { (dimensionless) }\end{array}$ & $\begin{array}{l}\text { Fragment } \\
\text { area }\left(\mathrm{km}^{2}\right)\end{array}$ \\
\hline \multirow[t]{3}{*}{ Downsized vs. Protected Lands } & $\mathrm{p}$ & $<0.001$ & $<0.001$ & 0.89 \\
\hline & $\mathrm{t}$ & 15.99 & 4.48 & 0.14 \\
\hline & df & 393.33 & 222.72 & 269.95 \\
\hline \multirow[t]{3}{*}{$\begin{array}{l}\text { Downsized vs. Never-Protected } \\
\text { Lands }\end{array}$} & $\mathrm{p}$ & $<0.001$ & 0.29 & 0.27 \\
\hline & $\mathrm{t}$ & -21.70 & -1.05 & 166.68 \\
\hline & df & 360.19 & 170.63 & 1.12 \\
\hline \multirow[t]{3}{*}{ Protected vs. Never-Protected Lands } & $\mathrm{p}$ & $<0.001$ & $<0.001$ & 0.07 \\
\hline & $\mathrm{t}$ & 105.09 & -14.12 & 1.81 \\
\hline & df & 7198.74 & 2063.51 & 1774.55 \\
\hline
\end{tabular}

${ }^{\dagger}$ Fragment: parcel of land surrounded by roads on all sides 
Table A1.8: Results of Fligner-Killeen tests for homoscedasticity for all land cover types indicating which statistical test(s) to perform next at all three spatial scales examined.

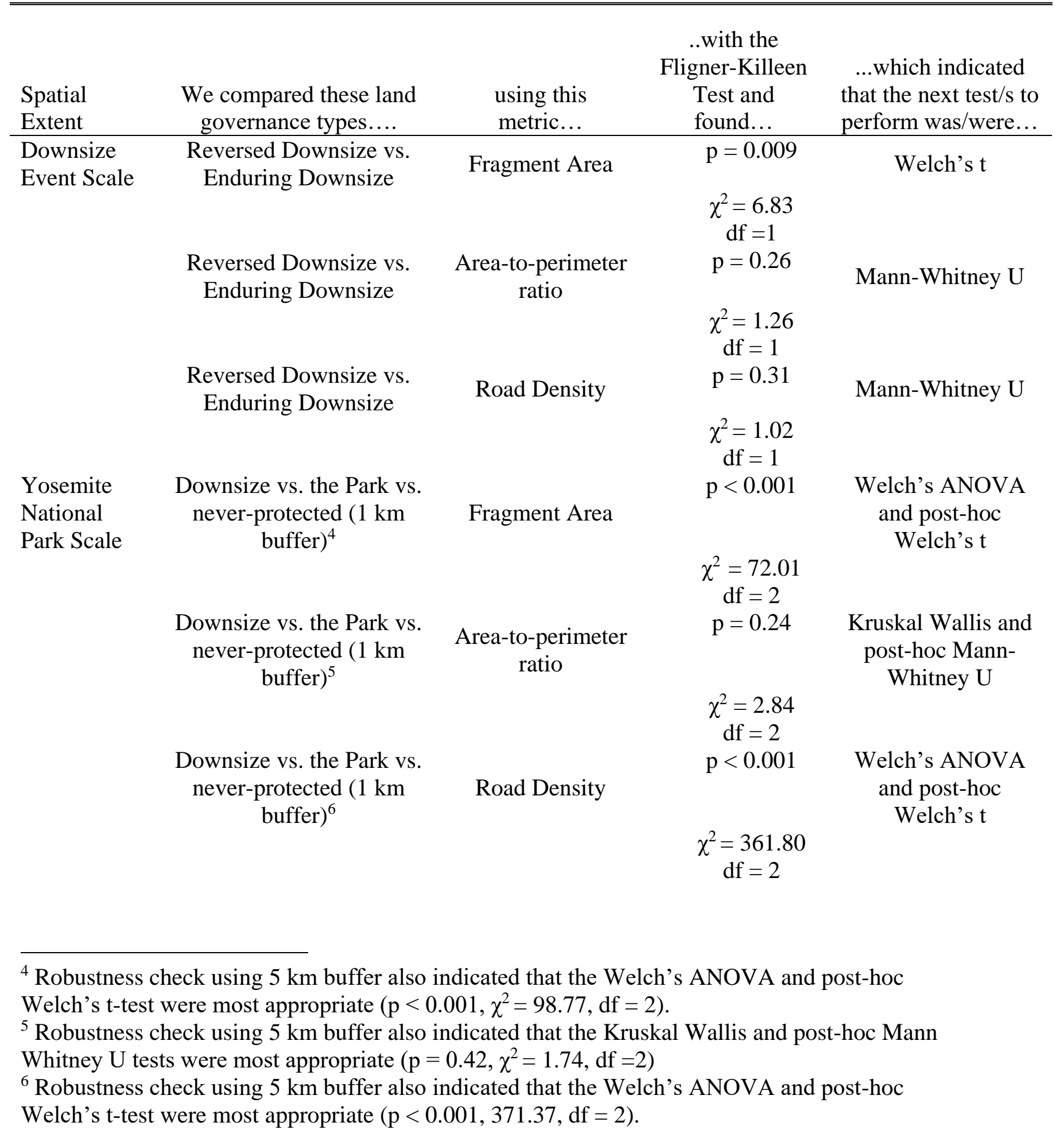


Sierra

Nevada

Ecoregion

Scale
Downsize vs. protected in the Ecoregion vs. neverprotected in the Ecoregion

Downsize vs. protected in the Ecoregion vs. neverprotected in the Ecoregion

Downsize vs. protected in the Ecoregion vs. neverprotected in the Ecoregion

$$
\mathrm{p}<0.001
$$

Fragment Area ratio

$$
\chi^{2}=408.59
$$$$
\mathrm{df}=2
$$$$
\mathrm{p}<0.001
$$

Road Density

$$
\chi^{2}=1075.38
$$$$
\mathrm{df}=2
$$$$
\mathrm{p}<0.001
$$$$
\chi^{2}=2986.43
$$$$
\mathrm{df}=2
$$

Welch's ANOVA and post hoc Welch's t
Welch's ANOVA and post hoc Welch's t

Welch's ANOVA
and post hoc
Welch's t


Table A1.9: Habitat fragmentation indicators in enduring and reversed downsizes for all land cover types.

\begin{tabular}{|c|c|c|c|c|}
\hline Land governance types & Statistics & Road density $\left(\mathrm{km}^{-1}\right)$ & $\begin{array}{c}\text { Fragment }^{\dagger} \text { area- } \\
\text { to-perimeter } \\
\text { ratio } \\
\text { (dimensionless) }\end{array}$ & $\begin{array}{l}\text { Fragment }{ }^{\dagger} \\
\text { area }\left(\mathrm{km}^{2}\right)\end{array}$ \\
\hline \multirow[t]{3}{*}{ Enduring downsizes } & $\begin{array}{c}\text { mean } \\
(\mathrm{SD})\end{array}$ & $1.10(0.38)$ & $0.028(0.017)$ & $2.43(8.78)$ \\
\hline & $\begin{array}{c}\text { median } \\
\text { (IQR) }\end{array}$ & $1.12(0.43)$ & $0.028(0.024)$ & $\begin{array}{l}0.067 \\
(1.32)\end{array}$ \\
\hline & $n$ & $265^{t}$ & $217^{\S}$ & $217^{\S}$ \\
\hline \multirow[t]{2}{*}{ Reversed downsizes } & $\begin{array}{l}\text { mean } \\
(\mathrm{SD})\end{array}$ & $0.37(0.45)$ & $0.030(0.018)$ & $\begin{array}{c}7.01 \\
(54.91)\end{array}$ \\
\hline & $\begin{array}{c}\text { median } \\
\text { (IQR) }\end{array}$ & $0.14(0.53)$ & $0.030(0.031)$ & $\begin{array}{l}0.045 \\
(0.43)\end{array}$ \\
\hline Results & $n$ & $\begin{array}{c}345^{\ddagger} \\
\mathrm{p}<0.001^{l} \\
\mathrm{~W}=11308\end{array}$ & $\begin{array}{c}96^{\S} \\
\mathrm{p}=0.22^{\mid} \\
\mathrm{W}=11316\end{array}$ & $\begin{array}{c}96^{\S} \\
\mathrm{p}=0.42^{\#} \\
\mathrm{df}=97.15 \\
\mathrm{t}=0.81\end{array}$ \\
\hline
\end{tabular}

$\dagger$ Fragment: parcel of land surrounded by roads on all sides

$\$$ Number of points sampled

$\S$ Number of fragments

I Mann-Whitney U test result; choice of test based on Fligner-Killeen test for homoscedasticity (see Table A1.8)

\# Welch's t-test result; choice of test based on Fligner-Killeen test for homoscedasticity (see Table A1.8) 
Table A1.10: Habitat fragmentation indicators for all land cover types at the Park scale. See Table A1.11 for results of post-hoc tests.

\begin{tabular}{|c|c|c|c|c|}
\hline Land governance type & Statistics & Road density $\left(\mathrm{km}^{-1}\right)$ & $\begin{array}{l}\text { Fragment }^{\dagger} \text { area- } \\
\text { to-perimeter } \\
\text { ratio } \\
\text { (dimensionless) }\end{array}$ & $\underset{\left(\mathrm{km}^{2}\right)}{\text { Fragment }}{ }^{\dagger}$ area \\
\hline \multirow[t]{3}{*}{ Downsizes } & mean $(\mathrm{SD})$ & $0.69(0.55)$ & $0.034(0.015)$ & $6.11(42.67)$ \\
\hline & & $0.80(1.03)$ & $0.034(0.024)$ & $0.11(1.11)$ \\
\hline & $n$ & $625^{+}$ & $201^{\S}$ & $201^{\S}$ \\
\hline \multirow[t]{3}{*}{ Yosemite National Park } & mean $(\mathrm{SD})$ & $0.27(0.32)$ & $0.041(0.015)$ & $15.67(144.50)$ \\
\hline & $\begin{array}{c}\text { median } \\
(\mathrm{IQR})\end{array}$ & $0.16(0.37)$ & $0.042(0.021)$ & $0.02(0.12)$ \\
\hline & $n$ & $1530^{\ddagger}$ & $193^{\S}$ & $193^{\S}$ \\
\hline \multirow{3}{*}{$\begin{array}{l}\text { Never-protected lands } \\
(1 \mathrm{~km} \text { buffer })\end{array}$} & mean $(\mathrm{SD})$ & $1.20(0.56)$ & $0.030(0.013)$ & $0.99(1.89)$ \\
\hline & $\begin{array}{c}\text { median } \\
(\mathrm{IQR})\end{array}$ & $1.31(0.67)$ & $0.029(0.017)$ & $\begin{array}{c}0.37 \\
(1.16)\end{array}$ \\
\hline & $n$ & 40 & $99^{\S}$ & $99^{\S}$ \\
\hline Results & & $\begin{array}{c}\mathrm{p}<0.001 \\
\mathrm{~F}=209.91 \\
\text { num } \mathrm{df}=2.00 \\
\text { denom } \mathrm{df}=100.63\end{array}$ & $\begin{array}{c}\mathrm{p}<0.001^{\#} \\
\chi^{2}=36.52 \\
\mathrm{df}=2\end{array}$ & $\begin{array}{c}\mathrm{p}=0.09 \\
\mathrm{~F}=2.43 \\
\text { num } \mathrm{df}=2.00 \\
\text { denom } \mathrm{df}= \\
262.32\end{array}$ \\
\hline
\end{tabular}

${ }^{\dagger}$ Fragment: parcel of land surrounded by roads on all sides

Number of points sampled

$\S$ Number of fragments

I Welch's ANOVA test result; choice of test based on Fligner-Killeen test for homoscedasticity (see Table A1.8)

${ }^{\#}$ Kruskal-Wallis test result; choice of test based on Fligner-Killeen test for homoscedasticity (see Table A1.8) 
Table A1.11: Habitat fragmentation at the Park scale for all land cover types. Never-protected lands delineated using a $1 \mathrm{~km}$ buffer. Results of post-hoc tests from Table A1.10.

\begin{tabular}{|c|c|c|c|}
\hline Comparison & $\begin{array}{l}\text { Road density } \\
\qquad\left(\mathrm{km}^{-1}\right)\end{array}$ & $\begin{array}{l}\text { Fragment }^{\dagger} \text { area- } \\
\text { to-perimeter } \\
\text { ratio } \\
\text { (dimensionless) }\end{array}$ & $\begin{array}{c}\text { Fragment }{ }^{\dagger} \text { area } \\
\qquad\left(\mathrm{km}^{2}\right)\end{array}$ \\
\hline Downsized vs. the Park & $\begin{array}{c}\mathrm{p}<0.001^{\ddagger} \\
\mathrm{t}=-17.97 \\
\mathrm{df}=804.00\end{array}$ & $\begin{array}{c}\mathrm{p}<0.001^{\S} \\
W=24395\end{array}$ & $\begin{array}{c}\mathrm{p}=0.38^{\ddagger} \\
\mathrm{t}=0.88 \\
\mathrm{df}=224.00\end{array}$ \\
\hline Downsized vs. Never-Protected & $\begin{aligned} \mathrm{p} & <0.001^{+} \\
\mathrm{t} & =5.63 \\
\mathrm{df} & =44.04\end{aligned}$ & $\begin{array}{c}\mathrm{p}=0.07^{\S} \\
\mathrm{W}=8680\end{array}$ & $\begin{aligned} \mathrm{p} & =0.09 \\
\mathrm{t} & =-1.70 \\
\mathrm{df} & =201.59\end{aligned}$ \\
\hline The Park vs. Never-Protected & $\begin{array}{c}\mathrm{p}=<0.001^{\ddagger} \\
\mathrm{t}=-10.56 \\
\mathrm{df}=39.69\end{array}$ & $\begin{array}{l}\mathrm{p}<0.001^{\S} \\
\mathrm{W}=4950\end{array}$ & $\begin{array}{c}\mathrm{p}=0.16^{+} \\
\mathrm{t}=1.41 \\
\mathrm{df}=192.19\end{array}$ \\
\hline
\end{tabular}

\footnotetext{
${ }^{\dagger}$ Fragment: parcel of land surrounded by roads on all sides

$\$$ Welch's t-test result. Choice of test based on Fligner-Killeen test for homoscedasticity (see Table A1.8)

$\S$ Mann-Whitney U test result. Choice of test based on Fligner-Killeen test for homoscedasticity (see Table A1.8)
} 
Table A1.12: Habitat fragmentation indicators at the Park scale for all land cover types sensitivity test using a $5 \mathrm{~km}$ never-protected lands buffer demonstrate the same results as with a $1 \mathrm{~km}$ buffer. See Table A1.13 for results of post-hoc tests.

\begin{tabular}{|c|c|c|c|c|}
\hline $\begin{array}{l}\text { Land governance } \\
\text { type }\end{array}$ & Statistics & $\begin{array}{c}\text { Road density }\left(\mathrm{km}^{-}\right. \\
1)\end{array}$ & $\begin{array}{l}\text { Fragment }^{\dagger} \text { area- } \\
\text { to-perimeter ratio } \\
\text { (dimensionless) }\end{array}$ & $\begin{array}{l}\text { Fragment }{ }^{\dagger} \text { area } \\
\qquad\left(\mathrm{km}^{2}\right)\end{array}$ \\
\hline \multirow[t]{3}{*}{ Downsizes } & mean (SD) & $0.69(0.55)$ & $0.034(0.015)$ & $6.12(42.67)$ \\
\hline & median (IQR) & $0.80(1.03)$ & $0.034(0.024)$ & $0.11(1.11)$ \\
\hline & $n$ & $625^{+}$ & $201^{\S}$ & $201^{\S}$ \\
\hline \multirow{3}{*}{$\begin{array}{l}\text { Yosemite } \\
\text { National Park }\end{array}$} & mean $(\mathrm{SD})$ & $0.27(0.32)$ & $0.041(0.015)$ & $15.67(144.50)$ \\
\hline & median (IQR) & $0.16(0.37)$ & $0.042(0.021)$ & $0.02(0.12)$ \\
\hline & $n$ & 1530 & $193^{\S}$ & $193^{\S}$ \\
\hline \multirow{3}{*}{$\begin{array}{l}\text { Never-protected } \\
\text { ( } 5 \mathrm{~km} \text { buffer) }\end{array}$} & mean $(\mathrm{SD})$ & $1.18(0.49)$ & $0.033(0.014)$ & $2.23(6.48)$ \\
\hline & median (IQR) & $1.29(0.73)$ & $0.032(0.019)$ & $0.25(1.69)$ \\
\hline & $n$ & $252^{\ddagger}$ & $217^{\S}$ & $217^{\S}$ \\
\hline \multirow[t]{4}{*}{ Results } & & $\mathrm{p}<0.001^{l}$ & $\mathrm{p}<0.001^{\#}$ & $\mathrm{p}=0.13^{\mid}$ \\
\hline & & $\mathrm{F}=555.14$ & $\chi^{2}=33.15$ & $\mathrm{~F}=2.04$ \\
\hline & & num df $=2.00$ & $\mathrm{df}=2$ & num $\mathrm{df}=2.00$ \\
\hline & & denom $\mathrm{df}=527.84$ & & $\begin{array}{c}\text { denom df }= \\
263.84\end{array}$ \\
\hline
\end{tabular}

$\uparrow$ Fragment: parcel of land surrounded by roads on all sides

$\$$ Number of points sampled

$\S$ Number of fragments

I Welch's ANOVA test result. Choice of test based on Fligner-Killeen test for homoscedasticity (see Table A1.8)

${ }^{\#}$ Kruskal-Wallis test result. Choice of test based on Fligner-Killeen test for homoscedasticity (see Table A1.8) 
Table A1.13: Post-hoc results from Table A1.12. Habitat fragmentation at the Park scale for all land cover types using $5 \mathrm{~km}$ buffers for never-protected lands. Results are consistent with comparisons using a $1 \mathrm{~km}$ buffer.

\begin{tabular}{lccc}
\hline \hline & $\begin{array}{c}\text { Fragment } \\
\text { to-perimeter } \\
\text { ratio }\end{array}$ & $\begin{array}{c}\text { Fragment } \\
\text { Comparison }\end{array}$ & $\begin{array}{c}\left.\mathrm{km}^{2}\right) \\
(\text { dimensionless })\end{array}$ \\
\hline Downsized vs. the Park & $\begin{array}{c}\mathrm{p}<0.001^{\ddagger} \\
\mathrm{t}=-17.97\end{array}$ & $\mathrm{p}<0.001^{\S}$ & $\mathrm{p}=0.38^{\ddagger}$ \\
& $\mathrm{df}=804.00$ & $\mathrm{t}=0.88$ \\
Downsized vs. Never & $\mathrm{p}<0.001^{\ddagger}$ & $\mathrm{p}=0.46^{\S}$ & $\mathrm{df}=224.00$ \\
Protected (5 km buffer) & $\mathrm{t}=12.944$ & $\mathrm{~W}=22172$ & $\mathrm{p}=0.20^{\ddagger}$ \\
& $\mathrm{df}=517.97$ & $\mathrm{t}=1.27$ \\
The Park vs. Never- & $\mathrm{p}<0.001^{\ddagger}$ & $\mathrm{p}<0.001^{\S}$ & $\mathrm{df}=208.55$ \\
Protected (5 km buffer) & $\mathrm{t}=-28.60$ & $\mathrm{~W}=23653$ & $\mathrm{t}=0.20^{\ddagger}$ \\
& $\mathrm{df}=287.76$ & $\mathrm{df}=192.69$ \\
\hline
\end{tabular}

$\dagger$ Fragment: parcel of land surrounded by roads on all sides

$\$$ Welch's t-test result. Choice of test based on Fligner-Killeen test for homoscedasticity (see Table A1.8)

${ }^{\S}$ Mann-Whitney U test result. Choice of test based on Fligner-Killeen test for homoscedasticity (see Table A1.8) 
Table A1.14: Habitat fragmentation indicators at the Ecoregional scale for all land cover types; results of Welch's ANOVA tests. See Table A1.15 for results of post-hoc tests.

\begin{tabular}{lcccc}
\hline \hline $\begin{array}{l}\text { Land governance } \\
\text { type }\end{array}$ & Statistics & $\begin{array}{c}\text { Road density } \\
\left(\mathrm{km}^{-1}\right)\end{array}$ & $\begin{array}{c}\text { Fragment } \\
\text { to-perimeter ratio } \\
(\text { dimensionless })\end{array}$ & $\begin{array}{c}\text { Fragment } \\
\left(\mathrm{km}^{2}\right)\end{array}$ \\
\hline Downsizes & mean (SD) & $0.69(0.55)$ & $0.034(0.015)$ & $6.11(42.67)$ \\
& median (IQR) & $0.80(1.03)$ & $0.034(0.024)$ & $0.11(1.11)$ \\
& $n$ & $625^{\ddagger}$ & $201^{\S}$ & $201^{\S}$ \\
All protected lands & & $0.29(0.43)$ & $0.025(0.020)$ & $4.90(78.81)$ \\
in Sierra Nevada & mean (SD) & & & \\
Ecoregion & median (IQR) & $0.11(0.38)$ & $0.021(0.034)$ & $0.01(0.11)$ \\
& $n$ & $8073^{\ddagger}$ & $3274^{\S}$ & $3274^{\S}$ \\
All never-protected & & $1.41(0.69)$ & $0.037(0.016)$ & $2.04(14.91)$ \\
lands in Sierra & mean (SD) & & & \\
Nevada Ecoregion & & & & $0.06(0.47)$ \\
& median (IQR) & $1.35(0.86)$ & $0.038(0.016)$ & $18,918^{\S}$ \\
Results & $n$ & $19,482^{\ddagger}$ & $<, 918^{\S}$ & 0.050 \\
& $\mathrm{p}$ & $<0.001$ & 6.001 & 3.03 \\
& $\mathrm{~F}$ & 13373.64 & 621.31 & 2.00 \\
& num df & 2.00 & 2.00 & 504.20 \\
\hline
\end{tabular}

${ }^{\dagger}$ Fragment: parcel of land surrounded by roads on all sides

$\$$ Number of points sampled

$\S$ Number of fragments 
Table A1.15: Habitat fragmentation at the Ecoregional scale for all land cover types -results of post-hoc Welch's t-tests from Table A1.14.

\begin{tabular}{|c|c|c|c|c|}
\hline Comparison & Statistics & $\begin{array}{l}\text { Road density } \\
\qquad\left(\mathrm{km}^{-1}\right)\end{array}$ & $\begin{array}{c}\text { Fragment }^{\dagger} \text { area- } \\
\text { to-perimeter } \\
\text { ratio } \\
\text { (dimensionless) }\end{array}$ & $\begin{array}{l}\text { Fragment } \\
\text { area }\left(\mathrm{km}^{2}\right)\end{array}$ \\
\hline \multirow[t]{3}{*}{ Downsized vs. Protected Lands } & $\mathrm{p}$ & $<0.001$ & $<0.001$ & 0.71 \\
\hline & $\mathrm{t}$ & -17.83 & 8.56 & -0.37 \\
\hline & df & 683.04 & 243.15 & 291.74 \\
\hline \multirow[t]{3}{*}{ Downsized vs. Never-Protected Lands } & $\mathrm{p}$ & $<0.001$ & 0.004 & 0.18 \\
\hline & $\mathrm{t}$ & -31.63 & -2.94 & 1.35 \\
\hline & df & 687.48 & 204.87 & 200.52 \\
\hline \multirow[t]{3}{*}{ Protected vs. Never-Protected Lands } & $\mathrm{p}$ & $<0.001$ & $<0.001$ & 0.039 \\
\hline & $\mathrm{t}$ & -165.85 & -35.23 & 2.07 \\
\hline & $\mathrm{df}$ & 22825.15 & 4078.28 & 3313.67 \\
\hline
\end{tabular}

$\dagger$ Fragment: parcel of land surrounded by roads on all sides 
Table A1.16: Fragment density calculations at three spatial scales for all land cover types

\begin{tabular}{|c|c|c|c|}
\hline Land governance type & $\begin{array}{c}\text { Total Area } \\
\left(\mathrm{km}^{2}\right)\end{array}$ & $\begin{array}{l}\text { Number of } \\
\text { fragments }^{\dagger}\end{array}$ & $\begin{array}{c}\text { Fragment }{ }^{\dagger} \\
\text { density }\left(\mathrm{km}^{-2}\right)\end{array}$ \\
\hline Enduring Downsize & 527.52 & 217 & 0.41 \\
\hline Reversed Downsize & 672.56 & 96 & 0.14 \\
\hline All Downsized lands & 1227.52 & 201 & 0.16 \\
\hline Yosemite National Park & 3025.11 & 193 & 0.06 \\
\hline Never-protected lands - $1 \mathrm{~km}$ buffer & 98.06 & 99 & 1.01 \\
\hline Never-protected lands- $5 \mathrm{~km}$ buffer & 484.79 & 217 & 0.45 \\
\hline All protected lands in the Ecoregion & 16026.33 & 3274 & 0.20 \\
\hline All never-protected lands in the Ecoregion & 38618.52 & 18918 & 0.49 \\
\hline
\end{tabular}

${ }^{\dagger}$ Fragment: parcel of land surrounded by roads on all sides 


\section{SUPPLEMENTAL LITERATURE CITED}

Greene, L. W. 1987. Yosemite: The Park and its Resources, Chapter III. [online] URL: http://www.yosemite.ca.us/library/yosemite_resources/early_calvary_years.html\#page_4 06 (accessed December 2012).

Homer, C.G., J. A. Dewitz, L. Yang, S. Jin, P. Danielson, G. Xian, G., J. Coulston, N. D. Herold, J. D. Wickham, K. and Megown. 2015. Completion of the 2011 National Land Cover Database for the conterminous United States-Representing a decade of land cover change information. Photogrammetric Engineering and Remote Sensing 81(5):345-354.

Huber, N. K. 1987. The Geologic Story of Yosemite National Park. Washington Government Printing Office, Washington DC.

Mascia, M.B., Pailler, S., Krithivasan, R. 2012. PADDDtracker.org Technical Guide (Version 1). World Wildlife Fund. Washington, D.C.

Olson, D. M. et al. 2001. Terrestrial Ecoregions of the World: A New Map of Life on Earth A new global map of terrestrial ecoregions provides an innovative tool for conserving biodiversity. BioScience 51:933-938.

Sexton, J.O., P. Noojipady, X.-P. Song, M. Feng, D.-X. Song, D.-H. Kim, A. Anand, C. Huang, S. Channan, S. L. Pimm, \& J. R. Townshend. 2016. Conservation policy and the measurement of forests. Nature Climate Change 6:192-196.

SFEI (San Francisco Estuary Institute) 2016. Maps and Scales. [online] URL: http://www.sfei.org/book/export/html/1321\#sthash.6KhL7BNa.dpbs

US Census Bureau. 2014. 2014 TIGER/Line Shapefiles (machine-readable data files). [online] URL: https://www.census.gov/geo/maps-data/data/tiger-line.html (accessed November 2014).

Wieczorek, J. 2001. MaNIS/HerpNet/ORNIS Georeferencing Guidelines. [online] URL: http://manisnet.org/GeorefGuide.html\#references 